\title{
a-Amylase Inhibitors: A Review of Raw Material and Isolated Compounds from Plant Source
}

Paloma Michelle de Sales, Paula Monteiro de Souza, Luiz Alberto Simeoni, Pérola de Oliveira Magalhães, Dâmaris Silveira

Department of Pharmaceutical Sciences, School of Health Sciences, Campus Darcy Ribeiro, University of Brasília, Brasília, Brazil.

Received, October 25, 2011; Revised, January 8, 2012; Accepted, January 23, 2012; Published, January 25, 2012.

\begin{abstract}
Inhibition of $\alpha$-amylase, enzyme that plays a role in digestion of starch and glycogen, is considered a strategy for the treatment of disorders in carbohydrate uptake, such as diabetes and obesity, as well as, dental caries and periodontal diseases. Plants are an important source of chemical constituents with potential for inhibition of $\alpha$-amylase and can be used as therapeutic or functional food sources. A review about crude extracts and isolated compounds from plant source that have been tested for $\alpha$-amylase inhibitory activity has been done. The analysis of the results shows a variety of crude extracts that present $\alpha$ amylase inhibitory activity and some of them had relevant activity when compared with controls used in the studies. Amongst the phyto-constituents that have been investigated, flavonoids are one of them that demonstrated the highest inhibitory activities with the potential of inhibition related to number of hydroxyl groups in the molecule of the compound. Several phyto-constituents and plant species as $\alpha$-amylase inhibitors are being reported in this article. Majority of studies have focused on the anti-amylase phenolic compounds.
\end{abstract}

This article is open to POST-PUBLICATION REVIEW. Registered readers (see "For Readers") may comment by clicking on ABSTRACT on the issue's contents page.

\section{INTRODUCTION}

Disorders of carbohydrate uptake may cause severe health problems such as diabetes (1), obesity (2), and oral diseases (3), all of which threaten an increasing worldwide population. Diabetes mellitus (DM) is a metabolic disorder resulting from deficiency in insulin secretion, insulin action, or both, promoting disturbance of carbohydrate, fat and protein metabolism. Longterm complications of diabetes mellitus include retinopathy, nephropathy, neuropathy, microangiopathy and increased risk of cardiovascular disease $(1,4,5)$.

The therapeutic strategies for the treatment of type 2 diabetes include the reduction of the demand for insulin, stimulation of endogenous insulin secretion, enhancement of the action of insulin at the target tissues and the inhibition of degradation of oligo and disaccharides (6). The drugs commonly used in clinic to handle or control diabetes are insulin, sulfonylureas, biguanide, glucosidase inhibitors, aldose reductase inhibitor, thiazolidinediones, carbamoylmethyl benzoic acid, insulin-like growth factor. The effect of these drugs is aimed to lower the level of blood glucose $(4,7,8)$. One therapeutic approach for treating type 2 diabetes mellitus is to decrease the post-prandial glucose levels. This could be done by retarding the absorption of glucose through the inhibition of the carbohydrates-hydrolysing enzymes, $\alpha$ glucosidase and $\alpha$-amylase, present in the small intestinal brush border that are responsible for the breakdown of oligosaccharides and disaccharides into monosaccharides suitable for absorption (1, $7,9,10)$. Inhibitors of these enzymes, like acarbose, delay carbohydrate digestion and prolong overall carbohydrate digestion time, causing a reduction in the rate of glucose absorption and consequently blunting the postprandial plasma glucose rise $(1,4)$.

Dental caries and periodontal diseases are the most prevalent oral infectious diseases that cause significantly impact a person's overall health, having considerable economic impact, if not adequate treated $(3,11)$.

\footnotetext{
Corresponding Author: Pérola de Oliveira Magalhães, Universidade de Brasília/UnB Faculdade de Ciências da Saúde, Departamento de Farmácia, Campus Universitário Darcy Ribeiro, Asa Norte CEP 70900-910, Brasília, Distrito Federal, Brasil. E-mail: perolamagalhaes@unb.br
} 
Take part in etiopathology of dental caries, the most abundant enzyme in human saliva, $\alpha$ amylase salivary, possess at least three distinct biological functions in the oral cavity (12). First, its hydrolytic activity is responsible for the initial break down of starch to oligosaccharides. Second, several lines of evidence indicate that salivary $\alpha$ amylase bound to tooth enamel or hydroxyapatite may play a role in dental plaque formation. Third, $\alpha$-amylase in solution binds with high affinity to viridans oral streptococci and bacteria-bound $\alpha$ amylase is capable of hydrolyzing starch to glucose, which can be used as a food source and then further metabolized to lactic acid. Localized acid production by bacteria can lead to the dissolution of tooth enamel, a critical step in dental caries progression $(12,13)$. Because of its central role in the oral cavity, $\alpha$-amylase salivary has been exploited as a target for the structureassisted design of compounds that might prevent unwanted dental plaque formation and the subsequent process of dental caries formation and progression. Ethnopharmacological approach and bioassay-guided isolation have provided a lead in identifying potential $\alpha$-amylase inhibitors from plant sources. Currently, methods to determine the levels of $\alpha$-amylase inhibitor are based on the measurement of $\alpha$-amylase activity resulting by the different iodine staining power in the presence or absence of an inhibitor during the action of the enzyme on soluble starch or by using an alkaline reactive whose brown reduction products are determined photometrically as reported by Bernfeld $(14,15)$. This review highlights on the plants and their active constituents so far reported to have $\alpha$-amylase inhibitory activity.

\section{CHARACTERISTICS OF $\alpha$-AMYLASE}

The $\quad \alpha$-amylase $\quad(\alpha \quad$-1,4-glucan-4glucanohydrolases; E.C. 3.2.1.1) is one of the major secretory products of the pancreas (about 5-6\%) (16) and salivary glands, playing a role in digestion of starch and glycogen and can be found in microorganisms, plants and higher organisms (17). The $\alpha$-amylase constitute a family of endoamylases that catalyse the initial hydrolysis of starch into shorter oligosaccharides through the cleavage of $\alpha$-D-(1-4) glycosidic bonds (17-20). Neither terminal glucose residues nor $\alpha-1,6-$ linkages can be cleaved by $\alpha$-amylase (16). The end products of $\alpha$-amylase action are oligosaccharides with varying length with an $\alpha$ configuration and $\alpha$-limit dextrins (21), which constitute a mixture of maltose, maltotriose, and branched oligosaccharides of 6-8 glucose units that contain both $\alpha-1,4$ and $\alpha-1,6$ linkages (16). Others amylolytic enzymes participate in the process of starch breakdown, but the contribution of $\alpha$-amylase is a prerequisite for the initiation of this process (19).

The human $\alpha$-amylase is classical calciumcontaining enzyme composed of 512 amino acids in a single oligosaccharide chain with a molecular weight of $57.6 \mathrm{kDa}(16)$. There are five $\alpha$-amylase genes clustered in chromosome 1, at location 1q21, in humans. Three of them code for salivary R-amylase, $A M Y 1 A, A M Y 1 B$, and $A M Y 1 C$, and the other two genes $A M Y 2 A$ and $A M Y 2 B$ are expressed in the pancreas $(22,23)$. Human salivary and pancreatic $\alpha$-amylases share a high degree of amino acid sequence similarity with $97 \%$ identical residues overall and $92 \%$ in the catalytic domains $(12,18)$.

The amylase presents a three-dimensional structure capable of binding to substrate and, by the action of highly specific catalytic groups, promote the breakage of the glycoside links (20). The protein contains 3 domains: $\mathrm{A}, \mathrm{B}$, and $\mathrm{C}$. Domain A, which has a $(\beta / \alpha)_{8}$ barrel fold, constitutes the catalytic core domain. It contains about 280-300 residues. The catalytic triad (Asp, Asp, Glu) is present in domain A $(24,25)$. The B domain is inserted between $\mathrm{A}$ and $\mathrm{C}$ domains and is attached to the A domain by disulphide bond. The $\mathrm{C}$ domain presents a $\beta$ sheet structure linked to the A domain by a simple polypeptide chain and seems to be an independent domain with unknown function. The active site (substratebinding) of the $\alpha$-amylase is situated in a long cleft located between the carboxyl end of both A and $\mathrm{B}$ domains. The calcium $\left(\mathrm{Ca}^{2+}\right)$ is situated between $\mathrm{A}$ and $\mathrm{B}$ domains and may act in stabilizing the three-dimensional structure and as an allosteric activator. The substrate-binding site contains 5 subsites $(-3-2-1+1+2)(26)$.

$\alpha$-Amylase catalyze the hydrolysis of starch via a double displacement mechanism involving the formation and hydrolysis of a covalent $\beta$ glycosyl enzyme intermediate by using active site carboxylic acids for it (27). The residues, in particular, $\mathrm{Asp}^{197}, \mathrm{Glu}^{233}$, and $\mathrm{Asp}^{300}$ were described to function as catalytic residues (26, 27). Probably, $\mathrm{Asp}^{197}$ acts as nucleophil that attacks the substrate at the sugar anomeric center, forming a covalently bound reaction intermediate. In this step, the reducing end of the substrate is cleaved off the sugar skeleton. In a second step a water molecule attacks the anomeric center to 
break the covalent bond between $\mathrm{Asp}^{197}$ and the substrate, attaching a hydroxyl group to the anomeric center. In both steps $\mathrm{Glu}^{233}$ and $\mathrm{Asp}^{300}$ either individually or collectively act as acid/base catalysts. As a consequence, the active site of human $\alpha$-amylase consists of several major binding subsites identified through kinetic studies (26). The same studies show that the "-1", "-2", and "- 3 " pocket is the core of the catalytic reaction (26).

\section{INHIBITORS OF $\alpha$-AMYLASE FROM PLANTS}

The potential role of the medicinal plants as inhibitors of $\alpha$-amylase has been reviewed by several authors. A variety of plants has been reported to show $\alpha$-amylase inhibitory activity and so may be relevant to the treatment of type 2 diabetes. About 800 plant species have been reported to possess antidiabetic properties. A wide range of plant-derived principles belonging to compounds, mainly alkaloids, glycosides, galactomannan gum, polysaccharides, hypoglycans, peptidoglycans, guanidine, steroids, glycopeptides and terpenoids, have demonstrated bioactivity against hyperglycaemia (28). A list of plants reported to have significant $\alpha$-amylase inhibitory activity is shown in Table 1.

Syzygium cumini L. (syn: Eugenia jambolana Lam.) and Psidium guajava L. are widely used traditional system of medicine to treat diabetes in India (29). The aqueous extracts from $S$. cumini seeds and $P$. guajava leaves both showed a dosedependent inhibitory effect on $\alpha$-amylase activity (29). The extract from seeds of $S$. cumini also significantly decreased the levels of blood glucose on diabetic rats $(28,30)$. Conforti and cols. $(2005)$ (31) demonstrated that methanol, ethyl acetate and hexane extracts from two varieties of Amaranthus caudatus L. seeds (Oscar blanco and Victor red. Oil) showed $\alpha$-amylase inhibitory activity (above $80 \%$ inhibition rate) at 0.25 $1 \mathrm{mg} / \mathrm{mL}$.

The buffered extracts of several plant species namely Balanites aegyptiaca L., Camellia sinensis L. Del., Galega officinalis L., Holarrhena floribunda (Don) Durand \& Schinz, Khaya senegalensis (Desr.) A. Juss., Melissa officinalis L., Mitragyna inermis (Willd.) O. Ktze., Rosmarinus officinalis L., Securidaca longepedunculata Fresen., Tamarindus indica L., Taraxacum officinale Web. ex Wigg., and Vaccinium myrtillus L. were screened for $\alpha$ amylase activity and showed remarkable inhibitory activity (above $45 \%$ inhibition rate at $0.2 \mathrm{~g} / \mathrm{mL}$ ) (6). Methanol extracts of 41 plants, used in traditional Mongolian medicine have been tested for $\alpha$-amylase inhibitory properties and significant inhibition of the enzyme was shown by Rhodiola rosea L., Ribes pullchelum Turcz, and Vaccinium uliginosum L; extracts from Geranium pretense L, Leontopodium ochroleucum Beauv., Paeonia anomala L., and Pentaphylloides fruticosa $\mathrm{L}$. Schwarz showed $\alpha$ amylase inhibitory activity greater than $30 \%$ (32). Loizzo and cols (2008) screened the methanol, hexane and chloroform extracts from nine Lebanon traditional medicinal plants recommended in Lebanon for diabetes and found that the methanol extracts of Salvia acetabulosa L. and Marrubium radiatum Devile ex Benth exerted the highest inhibitory activity against $\alpha$ amylase (33).

Ayurveda, the traditional Indian herbal medicinal system practiced for over thousands of years have reports of antidiabetic plants with no apparent known side effects $(34,35)$. Chloroform extracts of six plants namely Azadirachta indica A. Juss, S. cumini, Ocimum tenuflorum L., Murraya koenigii (L.) Spreng., and Linum usitatissimum L., traditionally used in Ayurveda along with Bougainvillea spectabilis Willd. used as a hypoglycemic plant in West Indies, and some parts of Asia were screened for inhibitory activity on $\alpha$-amylase (34). A significant inhibition was observed with extracts of O. tenuflorum (34). Other six Indian medicinal plants were tested for their effect on $\alpha$-amylase activity. Among them, Mangifera indica L., Embelia ribes Burm., Phyllanthus maderaspatensis Linn. and Punica granatum L. showed interesting $\alpha$-amylase inhibitory activity (36).

The proteinaceous inhibitor of $\alpha$-amylase $(\alpha \mathrm{AI})$, which inhibits animal salivary and pancreatic a-amylase, has been identified and isolated from various plant species (37). Amongst this plants, seeds of Phaseolus vulgaris L. contain proteinaceous inhibitors of the $\alpha$-amylase and the isoform inhibitor $\alpha \mathrm{AI}-1$ have been isolated and characterized $(38,39)$. The common bean $\alpha \mathrm{AI}-1$ has been reported to have relatively great potential as an extensive anti-obesity and antidiabetes remedy (37).

\section{PHYTOCONSTITUENTS WITH $\alpha$-AMYLASE INHIBITORY ACTIVITY}

A wide array of plant has derived numerous chemical compounds that have demonstrated 
activity consistent with their possible use in the treatment of diabetes. Research on new bioactive compounds from medicinal plants has led to isolation and structure elucidation of a number of exciting new pharmacophores. A list of phytoconstituents having significant $\alpha$-amylase inhibitory activity is provided in Table 2 .

Oligosaccharide inhibitors of the trestatin family that contain the acarviosine moiety (e.g., acarbose 1), proteinaceous inhibitors isolated from microbial sources and plant tissues (40) and molecules present in plants comprise the natural inhibitors of $\alpha$-amylase (41). Acarbose [1], a well know drug widely used for clinical treatment of diabetes mellitus, is a pseudotetrasaccharide, produced by Actinoplanes sp. fermentation, consisting of a polyhydroxylated aminocyclohexene derivative (valienamine) linked via its nitrogen atom to a 6-deoxyglucose, which is itself $\alpha-1,4$-linked to a maltose moiety. It is a competitive inhibitor of $\alpha$-amylase and the mechanism of inhibition seems to be due to the unsaturated cyclohexene ring and the glycosidic nitrogen linkage that mimics the transition state for the cleavage enzymatic of glycosidic linkages $(42,43)$.

In the structural study of the human pancreatic $\alpha$-amylase /acarbose complex, acarbose inhibitor was described to bind subsites "-3" through "+2" (26). In acarbose the valienamine moiety is found in binding subsite -1 and its strong inhibition is believed to result from enhanced binding of this moiety with the side chain of $\mathrm{Asp}^{197}$, $\mathrm{Glu}^{233}$, and $\mathrm{Asp}^{300}$. Kinetic studies also highlighted the importance in catalysis of the presence of hydroxyl groups in the ligand together with the $\mathrm{Asp}^{197}, \mathrm{Glu}^{233}$, and $\mathrm{Asp}^{300}$ residues in the binding site (substitution of these residues leading to a considerable drop in catalytic activity) (26).

Acarbose [1] is metabolised by small and large intestinal carbohydrases to give acarviosineglucose and glucose (43). The main adverse effects observed with acarbose are gastrointestinal, including abdominal discomfort, flatulence, meteorism and diarrhea $(8,43,44)$. These adverse effects might be caused by the increase of degradation products in the intestine resulting in the abnormal bacterial fermentation of undigested carbohydrates $(43,44)$. Indeed, these main side effects are common to $\alpha$-amylase inhibitors. Specifically, bloating, abdominal discomfort, diarrhea and flatulence occur in about $20 \%$ of patients (45). Frequently such effects lead to therapy discontinuation (7). $\alpha$-Glucosidase inhibitors are contraindicated in patients with irritable bowel syndrome or severe kidney or liver dysfunction. Inflammatory bowel disease is a relative contraindication (4). There are also reports of an increased of renal tumors occurrence and serious hepatic injury and acute hepatitis (46).

Studies with healthy and type 2 diabetes subjects showed that natural $\alpha$-amylases inhibitors isolated from wheat (47) and white bean (48) significantly reduced the peak of postprandial glucose. Inhibitory profiles were investigated in green, oolong and black teas and the results suggested that catechins may be responsible for its activity in human salivary $\alpha$-amylase (49).

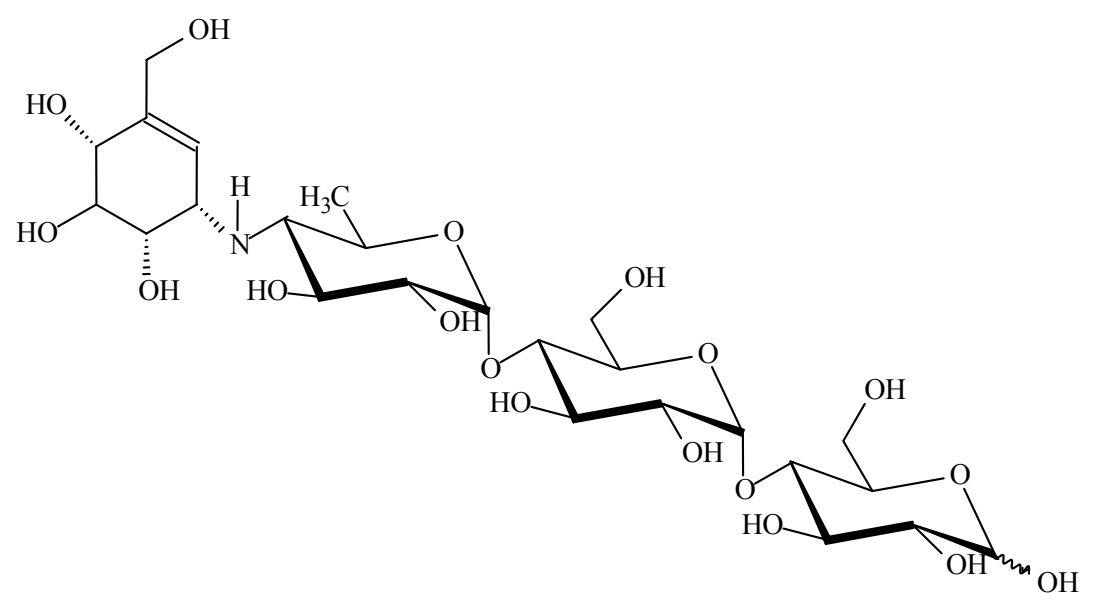

1 acarbose 
Therefore, the present article reviews and shows in table 1 a list of compounds with human $\alpha$ amylase inhibitory capacity.

Phenolic compounds are a large group of structurally diverse naturally occurring compounds that possess at least a phenolic moiety in their structures. Most of these compounds possess various degrees of antioxidant or free radical scavenging properties as well as medicinal properties and have long been used as drugs.

Flavonoids are abundant class of natural phenolic compounds with several biological activities. They share a common structural skeleton consisting of two aromatic rings (A and B) linked through three carbons attached to the Aring, forming an oxygenated heterocycle (ring C) and are divided in groups (Figure 1).<smiles>C1CCC(C2CCC3CCCCC3O2)CC1</smiles><smiles>O=C(Oc1ccccc1)c1cc(O)c2c(c1)OC(c1ccccc1)C(O)C2</smiles><smiles></smiles><smiles>Oc1cc(O)c2c(c1)OC(c1ccccc1)C(O)C2O</smiles>

anthocyanidin

flavandiol<smiles>[R]Oc1cc(O)c(C(=O)/C=C/c2ccccc2)c(O)c1</smiles>

chalcone<smiles>[R20]c1cc([R])c2c(=O)c(-c3ccccc3)coc2c1</smiles>

isoflavone

Figure 1. Flavonoids basic skeletons 
Lo Piparo et al. (2008) investigated the interactions between flavonoids and human $\alpha$ amylase in order to understand the molecular requirement for enzyme inhibition. They showed that the potency of inhibition is correlated with the number of hydroxyl groups on the B ring of the flavonoid skeleton. The interaction occurs with the formation of hydrogen bonds between the hydroxyl groups in position R6 or R7 of the ring A and position R4' or R5' of the ring $\mathrm{B}$ of the polyphenol ligands and the catalytic residues of the binding site and formation of a conjugated $\pi$-system that stabilizes the interaction with the active site (41). These results are in general agreement with the mechanism of action proposed for acarbose (50).

Tannins are another heterogenous polyphenol group widely distributed in the plant kingdom that are often present in unripe fruits, but can disappear during ripening. They have a relatively high molecular weight and can be classified into two major classes: hydrolysable tannins and condensed tannins. Hydrolysable tannins are subdivided into gallotannins, derived from gallic acid [2] units linked to a sugar moiety), while condensed tannins are complex polymers, where the building blocks are usually catechins and flavonoids (51).<smiles>O=C(O)c1cc(O)c(O)c(O)c1</smiles>

2 gallic acid

Several polyphenolic compounds presenting $\alpha$-amylase inhibitory activity are shown at Figures 2,3 , and 4 . Tannins could cause several effects on the biological system because they are potential metal ion chelators and protein precipitation agents forming insoluble complexes with proteins, as well as biological oxidants (52). Tannic acid and tannin-rich nonalcoholic components of red wine have been shown to reduce serum glucose levels after starch-rich meals in a study of patients with non-insulin dependent diabetes mellitus (53). As the mechanism involved in this anti-hyperglycemic effect is unknown, it is possible that tannins can inhibit $\alpha$-amylase activity in situ. The ability to strongly bind to proteins forming insoluble and indigestible complex is the basis of their extensive use in the leather industry (tanning process), and for the treatment of diarrhea, bleeding, skin injuries (54) and probably it is the action mechanism to cause inhibition of the enzyme $\alpha$ amylase.

Terpenoids are compounds that comprise various structures commonly found in nature with a several function in plants and animals. They usually arise from head-to-tail joining of isoprene units and a combination of two or more isoprene units divide the terpenoids in monoterpene $\left(\mathrm{C}_{10}\right)$, sesquiterpene $\left(C_{15}\right)$, diterpene $\left(C_{20}\right)$, sesterterpene $\left(\mathrm{C}_{25}\right)$, triterpene $\left(\mathrm{C}_{30}\right)$ and tetraterpene $\left(\mathrm{C}_{40}\right)(55)$.

Triterpenoids are a large and structurally diverse group of natural products derived from squalene [33] or related acyclic 30-carbon precursors (56) with several potential uses in medicine. Some triterpenoids with wellcharacterized biological activities include sterols, steroids, and saponins (57).

A range of real and potential usable biological effects are being studied for triterpenoids. Antiinflammatory, analgesic, antimicrobial, antimycotic, antiviral, antiplasmodial, antiulcerogenic, anticariogenic, immunomodulatory, vascular protective, antiobese, anticancer and tonic effects are ones the use related uses for this class of compound (58, 59). Hepato and cardioprotective activity were also related for triterpenoids (59-61). Triterpenoids represent a promising and expanding source for biologically active natural compounds whose potential for research and development of new substances with pharmacologic activity. However, despite the fact that triterpenoids are widely distribute in plants, inhibitory $\alpha$-amylase activity was related only for oleanane, ursane and lupane types and the mechanism by which this activity occur still unknown. Some terpenes presenting inhibitory activity on $\alpha$-amylase are shown at Figure 5.

\section{CONCLUSION}

$\alpha$-Amylase, a salivary or pancreatic enzyme plays an important role in early breakdown of complex carbohydrates into simple molecules. Modulation of $\alpha$-amylase activity affects the utilization of carbohydrates as an energy source and stronger is this modulation; more significant is the reduction is the breakdown of complex carbohydrates. Majority of studies have focused on the antiamylase phenolic compounds.

The action mechanism proposed for inhibitory capacity of flavonoids correlated the 
potency of inhibition of these compounds with the number of hydroxyl groups on the B ring of the flavonoid skeleton with the formation of hydrogen bounds between the hydroxyl groups of the polyphenol ligands and the catalytic residues of the binding site of the enzyme. The high inhibitory capacity is observed in flavonols and flavones groups.

The main inhibitory effects of the tannins is related with its the ability to strongly bind to carbohydrates and proteins. However, Kandra et al. (2004) suggested that the interaction between tannins, such galloylated quinic acid, and human $\alpha$-amylase is also correlated with free $\mathrm{OH}$ groups in the tannin, that are able to participate in hydrogen bonding (51). However, in this review is possible to note that tannins are not always an effective inhibitor of $\alpha$-amylase.

The significant differences in inhibitory activity for $\alpha$-amylase were shown in luteolin-7$O$-glucoside $[\boldsymbol{9 b}]$ from different studies. This compound showed $100 \%$ of inhibition in one study and $50 \%$ of inhibition in another. The same methodology was carried out to evaluate this activity in both studies, however the concentration of tested compound and incubation time of enzyme were different for both $(6,62)$.

Inhibitory activities ranging from $100 \%$ to $50 \%$ were also observed for fisetin $[4 c]$ and luteolin $[9 \boldsymbol{a}]$. The analyzed studies showed differences in the concentration of tested compound, incubation time of enzyme and substrate solution used $(6,41,62)$, and the impact that changes can be noted in the obtained results.

Differences in percentage of inhibition were also observed for rosmarinic acid [28] and daidzein $[15 a]$. Inhibitions of $85 \%$ and $50 \%$ for rosmarinic acid and $23 \%$ and $55 \%$ for daidzein were shown in the assays using starch and $\rho$ nitrophenyl- $\alpha$-D- maltopentaoside (PNPG) as a substrate, respectively $(6,41,62,63)$.

The comparison of inhibitory activity to $\alpha$ amylase showing in the studies allows to observe significant differences in percentage of inhibition for the same compound. This is due a several number of valuable assay methods for available the amylase activity. Between them, two types of assays are largely used to determine the action of $\alpha$-amylase. One is based on increase in reducing power of the substrate by the dinitrosalicylic acid (DNS) reagent (64), whereas the other is based on the change of the iodine- staining properties of the substrate (65). Thus, some modifications in this assays reported by researchers could express different results for $\alpha$-amylase inhibitory activity.
As the intake of phenolic compounds is associated with many beneficial effects, it is also necessary to consider the dose for humans, because it is possible to reduce $\alpha$-amylase activity by consuming food or medicinal herbs rich in polyphenols with strong $\alpha$-amylase activity, if it takes in consideration that this source of polyphenols possess different kinds of this compounds in variable concentration. Therefore, more available evidences are necessary about the safety of using natural $\alpha$-amylase inhibitor.

Also, there is need for novel agents, therapeutic strategies or designing functional foods that could act on the physiological regulation of sugar uptake, blood sugar levels, and prevention of oral diseases.

For the future, a standardized protocol to search potential inhibitors maybe should be designed in order to minimize the differences among obtained results.

\section{REFERENCES}

1. Laar FA, Lucassen PLBJ, Akkermans RP, Lisdonk EH, Rutten GEHM, Weel C. Alpha-glucosidase inhibitors for type 2 diabetes mellitus (Cochrane Review). The Cochrane Library, 2008.

2. Yanovski SZ, Yanovski JA. Drug Therapy: Obesity. N. Engl. J. Med., 2002; 346: 5991-602.

3. Touger-Decker R, Loveren CV. Sugars and dental caries. Am. J. Clin. Nutr., 2003; 78: 88S-92S.

4. Cheng AYY, Fantus IG. Oral antihyperglycemic therapy for type 2 diabetes Mellitus. Can. Med. Assoc. J., 2005; 172: 213-226.

5. Aguiar LGK, Villela NR, Bouskela EA. Microcirculação no Diabetes: Implicações nas Complicações Crônicas e Tratamento da Doença. Arq Bras Endocrinol Metab 2007; 51: 204-211.

6. Funke I, Melzing MF. Traditionally used plants in diabetes therapy - phytotherapeutics as inhibitors of $a$-amylase activity. Rev Bras Farmacogn, 2006; 16: $1-5$.

7. Inzucchi SE. Oral antihyperglycemic therapy for type 2 diabetes. JAMA, 2002; 287: 360-372.

8. Chakrabarti R, Rajagopalan R. Diabetes and insulin resistance associated disorders: Disease and the therapy. Current Sci, 2002; 83: 1533-1538.

9. Goke B, Herrmann-Rinke C. The evolving role of alpha-glucosidase inhibitors. Diabetes/Metab Res, 1998; 14: S31-S38.

10. Lebowitz HE. alpha-glucosidase inhibitors as agents in the treatment of diabetes Diabetes Rev, 1998; 6: 132-145.

11. Rudney JD. Saliva and dental plaque. Adv. Dental Res., 2000; 14: 29-39.

12. Ramasubbu N, Paloth V, Luo Y, Brayer GD, Levine MJ. Structure of human salivary alphaamylase at $1.6 \mathrm{~A}$ resolution: implications for its 
role in the oral cavity. Acta Crystallogr., Sect. D.: Biol. Crystallogr, 1996; 52: 435-446.

13. Scannapieco FA, Torres G, Levine MJ. Salivary $\alpha$ amylase: role in dental plaque and caries formation. Crit. Rev. Oral Biol. Med., 1993; 4: 301-307.

14. Bernfeld P. Amylases $\alpha$ and $\beta$. In Methods in Enzymology, Colowick, S. P.; Kaplan, N. O., Eds. Academic Press, Inc: San Diego, 1955; Vol. 1, pp 149-158.

15. Mosca M, Boniglia C, Carrat B, Giammarioli S, Nera V, Sanzini E. Determination of [alpha]amylase inhibitor activity of phaseolamin from kidney bean (Phaseolus vulgaris) in dietary supplements by HPAEC-PAD. Anal Chim Acta, 2008; 617: 192-195.

16. Whitcomb DC, Lowe ME. Human Pancreatic Digestive Enzymes. Digestive Diseases Sciences, 2007; 52: 1-17.

17. Kandra L. $\alpha$-Amylases of medical and industrial importance. J. Mol. Struct., 2003; 666-667: 487 498.

18. Brayer GD, Luo Y, Withers SG. The structure of human pancreatic a-amylase at $1.8 \mathrm{~A}$ resolution and comparisons with related enzymes. Protein Sci, 1995; 4: 1730-1742.

19. Tangphatsornruang $\mathrm{S}, \quad$ Naconsie $M$, Thammarongtham C, Narangajavana J. Isolation and characterization of an a-amylase gene in cassava (Manihot esculenta). Plant Physiol. Biochem., 2005; 43: 821-827.

20. Iulek J, Franco OL, Silva M, Slivinski CT, Bloch Jr C, Rigden DJ, Sám FG. Purification, biochemical characterisation and partial primary structure of a new $\alpha$-amylase inhibitor from Secale cereale (rye). Int. J. Biochem. Cell Biol, 2000; 32: 1195-1204.

21. Maarel MJEC, Veen B, Uitdehaag JCM, Leemhuis H, Dijkhuizen L. Properties and applications of starch-converting enzymes of the $\alpha$-amylase family. J. Biotechnol., 2002; 94: 137-155

22. Groot PC, Bleeker MJ, Pronk JC, Arwert F, Mager WH, Planta RJ, Eriksson AW, Frants RR. Human pancreatic amylase is encoded by two different genes. Nucleic Acids Res, 1988; 16: 4724.

23. Gumucio DL, Wiebauer K, Caldwell RM, Samuelson LC, Meisler MH. Concerted evolution of human amylase genes. Mol Cell Biol, 1988; 8: 1197-1205.

24. Van der Maarel MJEC, Van der Veen B, Uitdehaag JC, Leemhuis H, Dijkhuizen L. Properties and applications of starch-converting enzymes of the $\alpha$-amylase family J. Biotechnol., 2002; 94: 137-155.

25. Janecek S, Svensson B, Henrissat B. Domain evolution in the $\alpha$-amylase family. J. Mol. Evol., 1997; 45: 322-331.

26. Brayer GD, Sidhu G, Maurus R, Rydberg EH, Braun C, Wang Y, Nguyen NT, Overall CM, Withers SG. Subsite mapping of the human pancreatic alpha-amylase active site through structural, kinetic and mutagenesis techniques. Biochemistry-US, 2000; 39: 4778-4791.

27. Rydberg EH, Li C, Maurus R, Overall CM, Brayer GD, Withers SG. Mechanistic analyses of catalysis in human pancreatic $\alpha$-amylase: Detailed kinetic and structural studies of mutants of three conserved carboxylic acids. Biochemistry, 2002; 41: 4492-4502.

28. Mentreddy SR. Medicinal plant species with potential antidiabetic properties. J. Sci. Food Agric., 2007; 87: 743-750.

29. Karthic K, Kirthiram KS, Sadasivam S, Thayumanavan B. Identification of $\alpha$ - amylase inhibitors from Syzygium cumini Linn seeds. Indian J. Exp. Biol., 2008; 46: 677-680.

30. Kumar A, Ilavarasan R, Jayachandran $T$, Deecaraman M, Aravindan P, Padmanabhan N, Krishan M. Anti-diabetic activity of Syzygium cumini and it's isolated compound against streptozotocin-induced diabetic rats. J. Med. Plants Res., 2008; 2: 246-249.

31. Conforti F, Statti G, Loizzo MR, Sacchetti G, Poli F, Menichini F. In Vitro Antioxidant Effect and Inhibition of $a$-Amylase of Two Varieties of Amaranthus caudatus Seeds. Biol Pharm Bull, 2005; 28: 1098-1102.

32. Kobayashi K, Baba E, Fushiya S, Takano F, Batkhuu J, Dash T, Sanchir C, Yoshizaki F. Screening of Mongolian Plants for Influence on Amylase Activity in Mouse Plasma and Gastrointestinal Tube. Biol. Pharm. Bull., 2003; 26: $1045-1048$.

33. Loizzo MR, Saab AM, Tundis R, Menichini F, Bonesi M, Piccolo V, Statti GA, Cindio B, Houghton PJ. In vitro inhibitory activities of plants used in Lebanon traditional medicine against angiotensin converting enzyme (ACE) and digestive enzymes related to diabetes. J. Ethnopharm., 2008; 119: 109-116.

34. Bhat M, Zinjarde SS, Bhargava SY, Kumar AR, Joshi BN. Antidiabetic Indian plants: a good source of potent amylase inhibitors. Evid. Based Complement. Alternat. Med., 2011; 2011: 6 .

35. Bhutani KK, Gohil VM. Natural products drug discovery research in India: status and appraisal. Indian J Exp Biol, 2010; 48: 199-207.

36. Prashanth D, Padmaja R, Samiulla DS. Effect of certain plant extracts on [alpha]-amylase activity. Fitoterapia, 2001; 72: 179-181.

37. Wang HH, Chen CL, Jeng TL, Sung JM. Comparisons of [alpha]-amylase inhibitors from seeds of common bean mutants extracted through three phase partitioning. Food Chem., 2011; 128: 1066-1071.

38. Yamada T, Hattori K, Ishimoto M. Purification and characterization of two [alpha]-amylase inhibitors from seeds of tepary bean (Phaseolus acutifolius A. Gray). Phytochemistry, 2001; 58: 59-66.

39. Le Berre-Anton V, Bompard-Gilles C, Payan F, Rougé $\mathrm{P}$. Characterization and functional 
properties of the [alpha]-amylase inhibitor ([alpha]-AI) from kidney bean (Phaseolus vulgaris) seeds. Biochim. Biophys. Acta, 1997; 1343: 31-40.

40. Svensson B, Fukuda K, Nielsen PK, Bonsager BC. Proteinaceous a-amylase inhibitors. Biochim Biophys. Acta, 2004; 1696: 145-156.

41. Lo Piparo E, Scheib H, Frei N, Williamson G, Grigorov M, Chou CJ. Flavonoids for Controlling Starch Digestion: Structural Requirements for Inhibiting Human $\alpha$-Amylase. J. Med. Chem., 2008; 51: 3555-3561.

42. Yoon SH, Robyt JF. Study of the inhibition of four alpha amylases by acarbose and its $4 \mathrm{IV}-\alpha-$ maltohexaosyl and 4IV- $\alpha$-maltododecaosyl analogues. Carbohydr. Res., 2003; 338: 19691980.

43. Gyémánt G, Kandra L, Nagy V, Somsák L. Inhibition of human salivary $\alpha$-amylase by glucopyranosylidene-spiro-thiohydantoin.

Biochem Biophys Res Commun, 2003; 312: 334339.

44. Kwon YI, Apostolidis E, Shetty K. In vitro studies of eggplant (Solanum melongena) phrnolics as inhibitors of key enzymes relevant for type 2 diabetes and hypertension. Bioresour Technol, 2008; 99: 2981-2988.

45. Chiasson JL, Josse RG, Gomis R, Hanefeld M, Karasik A, Laakso M. Acarbose for prevention of type 2 diabetes mellitus: the STOP-NIDDM randomized trial. Lancet, 2002; 359: 2072-2077.

46. Murai A, Iwamura K, Takada M, Ogawa K, Usui T, Okamura J. Control of postprandial hyperglycaemia by galactosyl maltobionolactone and its novel anti-amylase effect in mice. Life Sci., 2002; 71: 1405-1415.

47. Lankisch M, Layer P, Rizza RA, DiMagno EP. Acute postprandial gastrointestinal and metabolic effects of wheat amylase inhibitor (WAI) in normal, obese, and diabetic humans. Pancreas, 1998; 17: 176-181.

48. Boivin M, Flourie B, Rizza RA, Go VL, DiMagno EP. Gastrointestinal and metabolic effects of amylase inhibition in diabetics. Gastroenterology, 1988; 94: 387-394.

49. Koh LW, Wong LL, Loo YY, Kasapis S, Huang D. Evaluation of Different Teas against Starch Digestibility by Mammalian Glycosidases. J Agric. Food Chem., 2010; 58: 148-154.

50. Brownlee M. The Pathobiology of Diabetic Complications: A Unifying Mechanism. Diabetes, 2005; 54: 1615-1625.

51. Kandra L, Gyémánt G, Zajácz A, Battab G. Inhibitory effects of tannin on human salivary aamylase. Biochem Biophys Res Commun, 2004; 319: 1265-1271.

52. Quideau S, Jourdes M, Saucier C, Glories Y, Pardon P, Baudry C. DNA topoisomerase inhibitor acutissimin $\mathrm{A}$ and other flavano-ellagitannins in red wine. Angew Chem. Int. Ed., 2003; 42: 60126014 .
53. Gin H, Rigalleau V, Caubet O, Aubertin J. Effects of red wine, tannic acid, or ethanol on glucose tolerance in non-insulin dependent diabetic patients and on starch digestibility in vitro. Metabolism, 1999; 48: 1179-1183.

54. Zajácz A, Gyémént G, Vittorib N, Kandraa L. Aleppo tannin: structural analysis and salivary amylase inhibition. Carbohydr. Res., 2007; 342: 717-723.

55. McGarvey DJ, Croteau R. Terpenoid metabolism. Plant Cell, 1995; 7: 1015-1026.

56. Connolly JD, Hill RA. Triterpenoids. Nat Prod Rep, 1999; 16: 221-240.

57. Xu R, Fazio GC, Matsuda SPT. On the origins of triterpenoid skeletal diversity. Phytochemistry, 2004; 65: 261-291.

58. Melo CL, Queiroz MG, Arruda Filho ACV, Rodrigues AM, Sousa DF, Almeida JG, Pessoa ODL, Silveira ER, Menezes DB, Melo TS, Santos FA, Rao VS. Betulinic acid, a natural pentacyclic triterpenoid, prevents abdominal fat accumulation in mice fed a high-fat diet. J. Agric. Food Chem., 2009; 57: 8776-8781.

59. Dzubak P, Hajduch M, Vydra D, Hustova A, Kvasnica M, Biedermann D, Markova L, Urban M, Sarek J. Pharmacological activities of natural triterpenoids and their therapeutic implications. Nat Prod Rep, 2006; 23: 394-411.

60. Tang X, Gao J, Chen J, Fang F, Wang Y, Dou H, $\mathrm{Xu} \mathrm{Q}$, Qian Z. Inhibition of ursolic acid on calcium-induced mitochondrial permeability transition and release of two proapoptotic proteins Biochem. Biophys. Res. Comm., 2005; 11: 320324.

61. Jeong HG, Kim HG, Hwang YP. Involvement of cytokines in the hepatic expression of metallothionein by ursolic acid Toxicol Lett, 2005; 155: 369-376.

62. Kim JS, Kwon CS, Son KH. Inhibition of alphaglucosidase and amylase by luteolin, a flavonoid Biosc. Biotechnol. Biochem., 2000; 64: 24582461.

63. McCue PP, Shetty K. Inhibitoy effects of rosmarinic acid extracts on porcine pancreatic amylase in vitro. Asia Pac. J. Clin. Nut., 2004; 13: 101-106.

64. Miller GL. Use of dinitrosalicylic acid reagent for determination of reducing sugar. Anal. Chem., 1959; 31: 426-428.

65. Fuwa H. A New method for microdetermination of amylase activity by the use of amylose as the substrate. J. Biochem, 1954; 41: 583-603.

66. Subramanian R, Asmawi MZ, Sadikun A. In vitro alpha-glucosidase and alpha-amylase enzyme inhibitory effects of Andrographis paniculata extract and andrographolide. Acta Biochim. Pol., 2008; 55: 391-398.

67. Shirosaki M, Koyama T, Yazawa K. Antihyperglycemic activity of kiwifruit leaf (Actinidia deliciosa) in mice. Biosc. Biotechnol. Biochem., 2008; 72: 1099-1102. 
68. Al-Dabbas MM, Kitahara K, Suganuma T, Hashimoto F, Tadera K. Antioxidant and aAmylase Inhibitory Compounds from Aerial Parts of Varthemia iphionoides Boiss. Biosci. Biotech. Biochem., 2006; 70: 2178-2184.

69. Silva Pinto M, Kwon YI, Apostolidis E, Lajolo FM, Genovese MI, Shetty K. Potential of Ginkgo biloba L. leaves in the management of hyperglycemia and hypertension using in vitro models. Biores. Technol., 2009; 100: 6599-6609.

70. Ali H, Houghton PJ, Soumyanath A. alpha amylase inhibitory activity of some Malaysian plants used to treat diabetes; with particular reference to Phyllanthus amarus. J. Ethnopharmacol., 2006; 107: 449-455.

71. Giri AP, Kachole MS. Amylase inhibitors of pigeonpea (Cajanus cajan) seeds. Phytochemistry, 1998; 47: 197-202.

72. Guzman-Partida A, Jatomea-Fino O, RoblesBurgueño M, Ortega-Nieblas M, Vazquez-Moreno L. Characterization of [alpha]-amylase inhibitor from Palo Fierro seeds. Plant Physiology and Biochemistry, 2007; 45: 711-715.

73. Hansawasdi C, Kawabata J, Kasai T. \&alpha;Amylase Inhibitors from Roselle (Hibiscus sabdariffa Linn.) Tea. Biosc. Biotechnol. Biochem., 2000; 64: 1041-1043.

74. Thalapaneni NR, Chidambaram KA, Ellappan T, Sabapathi ML, Mandal SC. Inhibition of Carbohydrate Digestive Enzymes by Talinum portulacifolium (Forssk) Leaf Extract. J. Complem. Integr. Med., 2008; 5: 11.
75. Bhandari MR, Jong-Anurakkun N, Gao Hong JK. $a$-Glucosidase and $a$-amylase inhibitory activities of Nepalese medicinal herb Pakhanbhed (Bergenia ciliata, Haw.). Food Chem, 2008; 106: 247-252.

76. Mohamed GA. Alliuocide G, a new flavonoid with potent $\alpha$-amylase inhibitory activity from Allium cepa L. Arkivoc, 2008; 9: 202-209.

77. Kawaguchi M, Tanabe H, Nagamine K. Isolation and characterization of a novel flavonoid possessing a 4,2"-glycosidic linkage from green mature acerola (Malpighia emarginata DC.) fruit. Biosc. Biotechnol. Biochem., 2007; 71: 11301135 .

78. Jullian C, Miranda S, Zapata-Torres G, Mendiza'balc F, Olea-Azarb C. Studies of inclusion complexes of natural and modified cyclodextrin with $(+)$ catechin by NMR and molecular modeling. Bioorg. Med. Chem., 2007; 15: 3217-3224.

79. Fred-Jaiyesimi A, Kio A, Richard W. $\alpha$-Amylase inhibitory effect of 3 $\beta$-olean-12-en-3-yl (9Z)hexadec-9-enoate isolated from Spondias mombin leaf Food Chem, 2009; 116: 285-288.

80. McDougall GJ, Shpiro F, Dobson P, Smith P, Blake A, Stewart D. Different polyphenolic components of soft fruits inhibit $\alpha$-amylase and $\alpha$ glucosidase. J. Agric. Food Chem., 2005; 53: 2760-2766.

81. Ani V, Akhilender Naidu K. Antihyperglycemic activity of polyphenolic components of black/bitter cumin Centratherum anthelminticum (L.) Kuntze seeds. Eu Food Res Technol, 2008; 226: 897-903. 


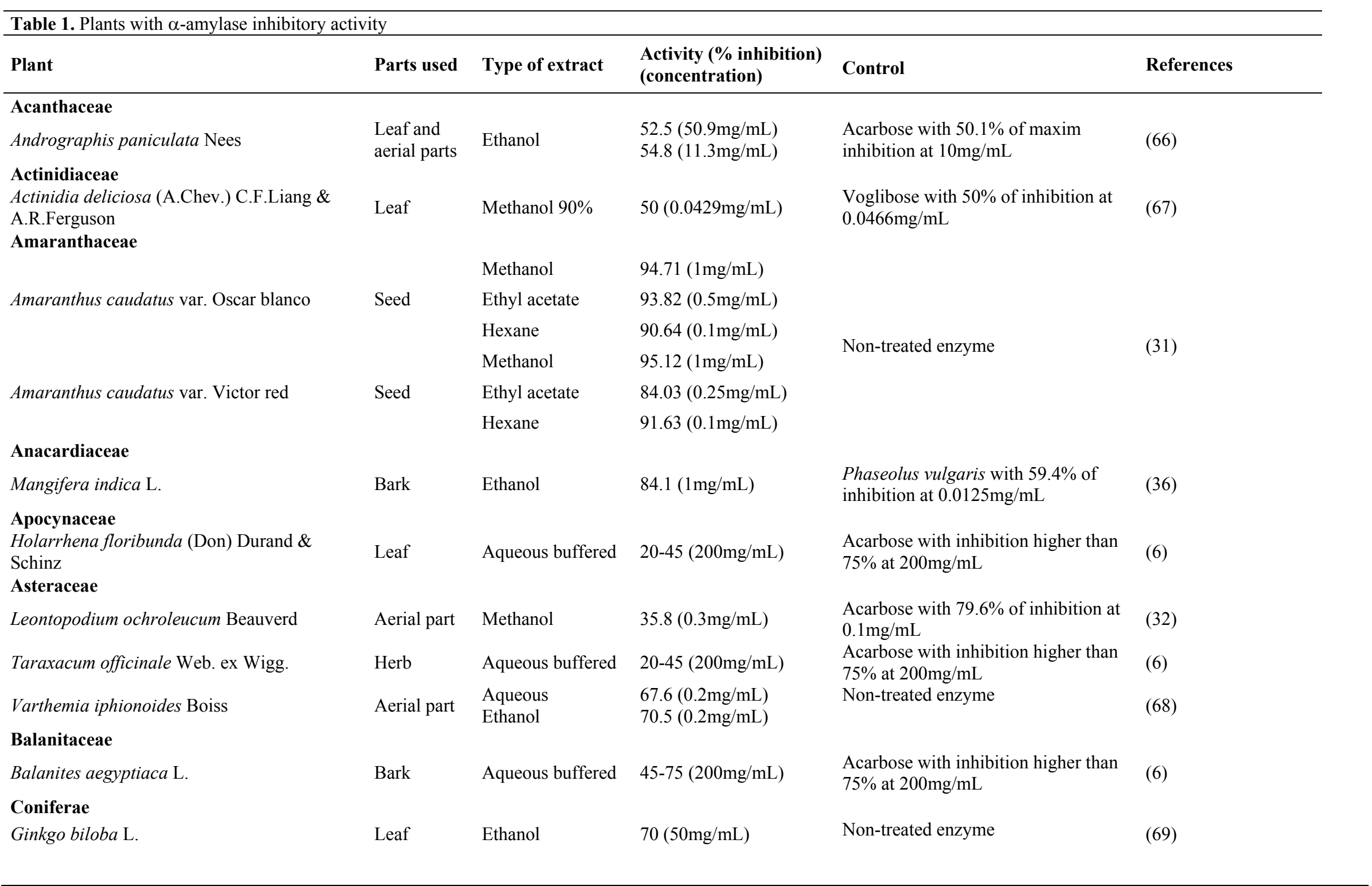




\section{Crassulaceae}

Rhodiola rosea $\mathrm{L}$.

\section{Ericaceae}

Vaccinium myrtillus L.

Vaccinium uliginosum $\mathrm{L}$.

\section{Euphorbiaceae}

Phyllanthus amarus Schum. et Thonn.

Phyllanthus maderaspatensis $\mathrm{L}$

\section{Geraniaceae}

Geranium pratense L.

\section{Grossulariaceae}

Ribes pulchellum Turcz.

\section{Lamiaceae}

Marrubium radiatum Delile ex Benth.

Melissa officinalis L.

Ocimum tenuflorum L.

Origanum vulgare L.

Rosmarinus officinalis $\mathrm{L}$.

Salvia acetabulosa $\mathrm{L}$

\section{Fabaceae}

Cajanus cajan $\mathrm{L}$

Galega officinalis L.

\section{Rhizome}

Methanol

$78(0.3 \mathrm{mg} / \mathrm{mL})$

Leaf

Leaf and

wood

Aqueous buffered $>75(200 \mathrm{mg} / \mathrm{mL})$

Methanol

$80.7(0.3 \mathrm{mg} / \mathrm{mL})$

Whole plant Hexane

$24.3(1 \mathrm{mg} / \mathrm{mL})$

Whole plant Ethanol

$47.6(1 \mathrm{mg} / \mathrm{mL})$

Aerial part Methanol

$43.9(0.3 \mathrm{mg} / \mathrm{mL})$

Aerial part Methanol

$78.9(0.3 \mathrm{mg} / \mathrm{mL})$

Aerial part

Methanol

$50(0.0611 \mathrm{mg} / \mathrm{mL})$

Ethanol

$50(3.33 \mathrm{mg} / \mathrm{mL})$

Leaf

Aqueous buffered $50(200 \mathrm{mg} / \mathrm{mL})$

Leaf

Leaf

Chloroform

$24.57(10 \mathrm{mg} / \mathrm{mL})$

Ethanol

$42(3.33 \mathrm{mg} / \mathrm{mL})$

Leaf

Aqueous buffered

$60(200 \mathrm{mg} / \mathrm{mL})$

Aerial part

Methanol

$50(0.0912 \mathrm{mg} / \mathrm{mL})$

Seed

Herb

\section{Aqueous buffered 100 (2mg protein)}

Aqueous buffered
Acarbose with $79.6 \%$ of inhibition at

$0.1 \mathrm{mg} / \mathrm{mL}$

Acarbose with inhibition higher than $75 \%$ at $200 \mathrm{mg} / \mathrm{mL}$

Acarbose with $79.6 \%$ of inhibition at

$0.1 \mathrm{mg} / \mathrm{mL}$

Triticum aestivum with $32 \%$ of inhibition at 5 unit $/ \mathrm{mL}$

Phaseolus vulgaris with $59.4 \%$ of inhibition at $0.0125 \mathrm{mg} / \mathrm{mL}$

Acarbose with $79.6 \%$ of inhibition at $0.1 \mathrm{mg} / \mathrm{mL}$

Acarbose with $79.6 \%$ of inhibition at $0.1 \mathrm{mg} / \mathrm{mL}$

Acarbose with $50 \%$ of inhibition at $0.05 \mathrm{mg} / \mathrm{mL}$

Non-treated enzyme

Acarbose with inhibition higher than $75 \%$ at $200 \mathrm{mg} / \mathrm{mL}$

Acarbose with $50 \%$ of inhibition at $1.22 \mathrm{mg} / \mathrm{mL}$

Non-treated enzyme

Acarbose with inhibition higher than $75 \%$ at $200 \mathrm{mg} / \mathrm{mL}$

Acarbose with $50 \%$ of inhibition at $0.05 \mathrm{mg} / \mathrm{mL}$

Non-treated enzyme

Acarbose with inhibition higher than $75 \%$ at $200 \mathrm{mg} / \mathrm{mL}$ 
J Pharm Pharmaceut Sci (www.cspsCanada.org) 15(1) 141 - 183, 2012

Olneya tesota A.Gray

Phaseolus vulgaris L.

Tamarindus indica $\mathrm{L}$.

\section{Malvaceae}

Hibiscus sabdariffa Linn.

\section{Meliaceae}

Khaya senegalensis (Desr.) A. Juss.

\section{Myrsinaceae}

Embelia ribes Burm. f.

Myrtaceae

Psidium guajava var. Pomiferum

Psidium guajava L.

Syzygium cumini (L.) Skeels

\section{Nyctaginaceae}

Bougainvillea spectabilis Wild.

\section{Paeoniaceae}

Paeonia anomala $\mathrm{L}$.

\section{Pinaceae}

Cedrus libani A. Rich

\section{Polygalaceae}

Securidaca longepedunculata Fresen.

\section{Portulacaceae}

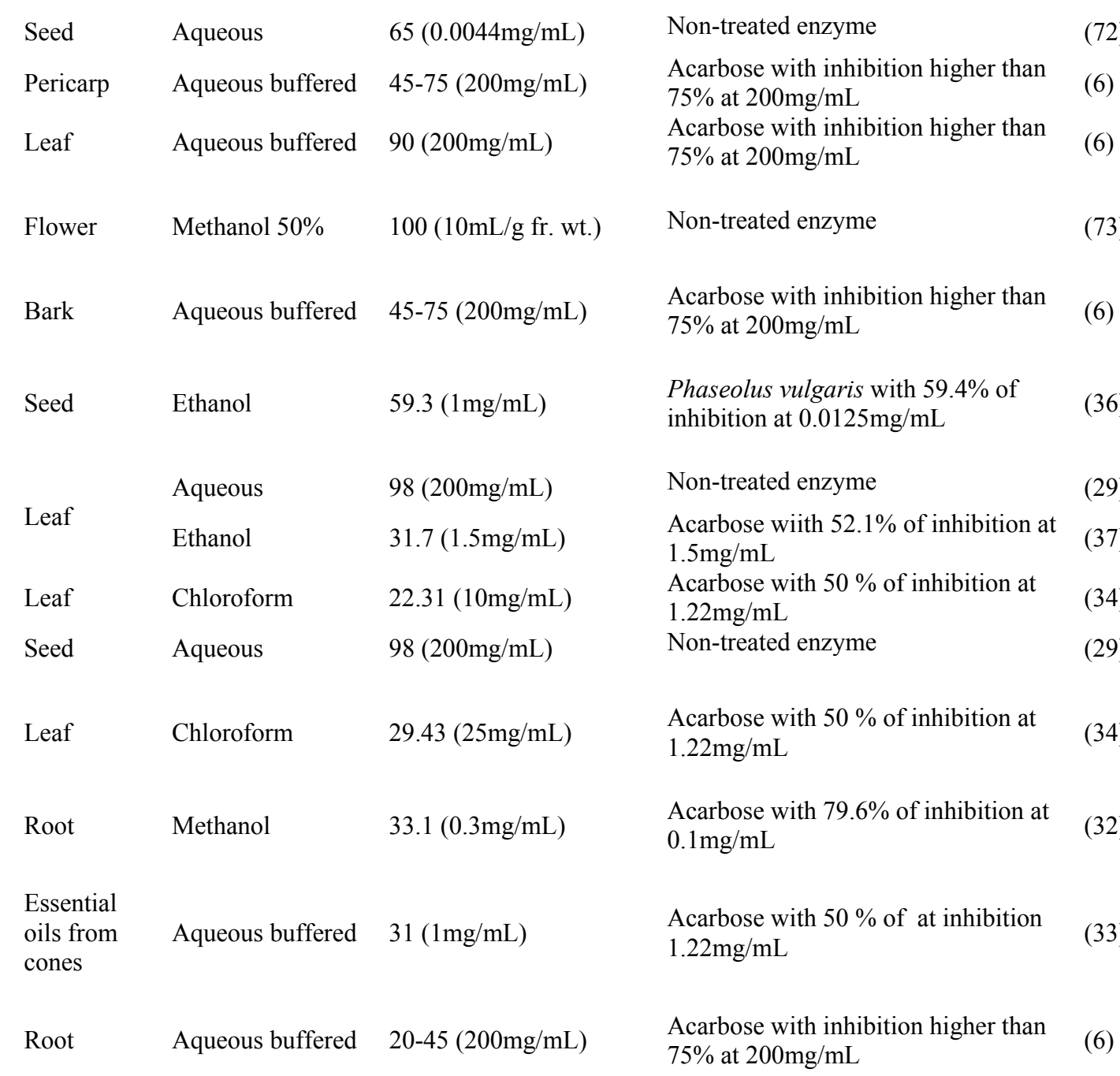


Talinum portulacifolium Asch. Ex Schweinf. Leaf

\section{Punicaceae}

Punica granatum L.

\section{Rosaceae}

Pentaphylloides fruticosa (L.) O.Schwarz

Rubiaceae

Mitragyna inermis (Willd.) O. Ktze.

Rutaceae

Murraya koenigii L.

\section{Saxifragaceae}

Bergenia ciliata, Haw.

\section{Theaceae}

Camellia sinensis L. Del.
Methanol

$60.66(1 \mathrm{mg} / \mathrm{mL})$

Fruit rind

Ethanol

$68.2(1 \mathrm{mg} / \mathrm{mL})$

Leaf and branch

Methanol

$31.2(0.3 \mathrm{mg} / \mathrm{mL})$

Leaf

Aqueous buffered

$75(200 \mathrm{mg} / \mathrm{mL})$

Leaf

Chloroform

Methanol 50\%

Aqueous

Ethyl acetate
$56.64(25 \mathrm{mg} / \mathrm{mL})$

$93.5(150 \mathrm{mg} / \mathrm{mL})$

$65.3(150 \mathrm{mg} / \mathrm{mL})$

$84.3(150 \mathrm{mg} / \mathrm{mL})$
Acarbose with $50.33 \%$ of inhibition at

$0.05 \mathrm{mg} / \mathrm{mL}$

Phaseolus vulgaris with $59.4 \%$ of inhibition at $0.0125 \mathrm{mg} / \mathrm{mL}$

Acarbose with $79.6 \%$ of inhibition at $0.1 \mathrm{mg} / \mathrm{mL}$

Acarbose with inhibition higher than $75 \%$ at $200 \mathrm{mg} / \mathrm{mL}$

Acarbose with $50 \%$ of at inhibition $1.22 \mathrm{mg} / \mathrm{mL}$

Non-treated enzyme

Acarbose with inhibition higher than $75 \%$ at $200 \mathrm{mg} / \mathrm{mL}$

Table 2. Natural compounds with $\alpha$-amylase inhibition

\begin{tabular}{|c|c|c|c|c|}
\hline Compound & Source & Activity & Control & Reference \\
\hline \multicolumn{5}{|l|}{ Flavonol } \\
\hline quercetin $(3 a)$ & - & $\begin{array}{l}82 \% \text { of inhibitory activity }(50 \% \\
\text { inhibition at } 21,4 \mu \mathrm{M})\end{array}$ & $\begin{array}{l}\text { Acarbose with } 99 \% \text { of maxim inhibition } \\
(50 \% \text { inhibition at } 0,996 \mu \mathrm{M})\end{array}$ & $(41)$ \\
\hline 3,7,3'-trimethoxy quercetin $(3 \boldsymbol{b})$ & $\begin{array}{l}\text { Varthemia iphionoides Boiss. } \\
\text { \& Blanche (Asteraceae) }\end{array}$ & $32 \%$ of inhibitory activity $(100 \mu \mathrm{M})$ & Non-treated enzyme & $(68)$ \\
\hline quercetrin $(3 c)$ & $\begin{array}{l}\text { Kalopanax pictum } \\
\text { (Araliaceae) }\end{array}$ & $\begin{array}{l} \pm 45 \% \text { of inhibitory activity } \\
(5 \mathrm{mg} / \mathrm{mL})\end{array}$ & $\begin{array}{l}\text { Acarbose with } 50 \% \text { inhibition at } 5 \text { - } \\
50 \mu \mathrm{g} / \mathrm{mL}\end{array}$ & $(62)$ \\
\hline rutin $(3 d)$ & $\begin{array}{l}\text { Sophora japonica } \\
\text { L.(Leguminosae) }\end{array}$ & $\begin{array}{l} \pm 40 \% \text { of inhibitory activity } \\
(5 \mathrm{mg} / \mathrm{mL})\end{array}$ & $\begin{array}{l}\text { Acarbose with } 50 \% \text { inhibition at } 5 \text { - } \\
50 \mu \mathrm{g} / \mathrm{mL}\end{array}$ & $(62)$ \\
\hline kaempferol $(3 \boldsymbol{e})$ & - & $34 \%$ of inhibitory activity $(50 \%$ & Acarbose with $99 \%$ of maxim inhibition & $(41)$ \\
\hline
\end{tabular}


5,7,4'- trihydroxy-3methoxyflavone $(3 f)$ 5,4' - dihydroxy-3,7dimethoxyflavone $(3 \boldsymbol{g})$ 5,4 '- dihydroxy-3, 6, 7trimethoxyflavone $(3 \boldsymbol{h})$

astragalin $(3 i)$

hyperin $(3 j)$

isorhamnetin $(4 a)$

$\operatorname{narcisin}(4 b)$

fisetin $(4 c)$

myricetin $(4 d)$

quercetin dimer $(5 \boldsymbol{a})$ (4'-O- $\beta$-D-glucopyranoside of quercetin dimer) $(\mathbf{5} \boldsymbol{b})$

Quercetagetin (6)

kaempferol-3- O-[6"-O-(3hydroxy-3-methylglutaroyl) glucoside] (7)

auranetin-5-methylether $(\boldsymbol{8})$ inhibition was not determined)

Varthemia iphionoides Boiss

\& Blanche (Asteraceae)

Varthemia iphionoides Boiss.

\& Blanche (Asteraceae)

Varthemia iphionoides Boiss

$\&$ Blanche (Asteraceae)

Polygala japonica Houtt.

(Polygalaceae)

Kalopanax pictum

(Araliaceae)

Sophora japonica $\mathrm{L}$

(Leguminosae)

Allium cepa L. (Liliaceae)

Allium cepa L. (Liliaceae)

Polygala japonica Houtt.

(Polygalaceae)

Varthemia iphionoides Boiss. \& Blanche (Asteraceae)

$\pm 55 \%$ of inhibitory activity

$(5 \mathrm{mg} / \mathrm{mL})$

$\pm 55 \%$ of inhibitory activity

$(5 \mathrm{mg} / \mathrm{mL})$ inhibition was not determined)

$\pm 70 \%$ of inhibitory activity

$(5 \mathrm{mg} / \mathrm{mL})$
$99 \%$ of inhibitory activity $(100 \mu \mathrm{M}) \quad$ Non-treated enzyme

$98 \%$ of inhibitory activity $(100 \mu \mathrm{M}) \quad$ Non-treated enzyme

$77 \%$ of inhibitory activity $(100 \mu \mathrm{M}) \quad$ Non-treated enzyme

$35 \%$ of inhibitory activity $(50 \%$

Acarbose with 50\% inhibition at 5-

$50 \mu \mathrm{g} / \mathrm{mL}$

Acarbose with 50\% inhibition at 5-

$50 \mu \mathrm{g} / \mathrm{mL}$

Acarbose with $99 \%$ of maxim inhibition

$(50 \%$ inhibition at $0,996 \mu \mathrm{M})$

Acarbose with 50\% inhibition at 5-

$50 \mu \mathrm{g} / \mathrm{mL}$

$50 \%$ inhibition between $0,4-0,6 \mathrm{mM}$ Acarbose with 50\% inhibition at $<$

$0,1 \mathrm{mM}$

85 (50\% inhibition at $19,6 \mu \mathrm{M})$

Acarbose with $99 \%$ of maxim inhibition

$(50 \%$ inhibition at $0,996 \mu \mathrm{M})$

Acarbose with $99 \%$ of maxim inhibition

$(50 \%$ inhibition at $0,996 \mu \mathrm{M})$

Acarbose

Acarbose

Acarbose with $99 \%$ of maxim inhibition

$(50 \%$ inhibition at $0,996 \mu \mathrm{M})$

Acarbose with 50\% inhibition at 5-

$50 \mu \mathrm{g} / \mathrm{mL}$

$18 \%$ of inhibitory activity $(100 \mu \mathrm{M}) \quad$ Non-treated enzyme

\section{Flavone}

Luteolin $(9 a)$
Lonicera japonica Thunb.

(Caprifoliaceae)
$100 \%$ of inhibitory activity

$(5 \mathrm{mg} / \mathrm{mL})$
Acarbose with 50\% inhibition at

$5-50 \mu \mathrm{g} / \mathrm{mL}$
(62) 


\begin{tabular}{|c|c|c|c|c|}
\hline & - & $50 \%$ inhibition at $0,2 \mathrm{mM}$ & $\begin{array}{l}\text { Acarbose with } 50 \% \text { inhibition at } \\
<0,1 \mathrm{mM}\end{array}$ & (6) \\
\hline & - & $\begin{array}{l}88 \% \text { of inhibitory activity }(50 \% \\
\text { inhibition at } 18,4 \mu \mathrm{M})\end{array}$ & $\begin{array}{l}\text { Acarbose with } 99 \% \text { of maxim } \\
\text { inhibition }(50 \% \text { inhibition at } \\
0,996 \mu \mathrm{M})\end{array}$ & $(41)$ \\
\hline \multirow{3}{*}{ luteolin -7-O-glucoside $(\mathbf{9 b})$} & Allium cepa L. (Liliaceae) & $\begin{array}{l}82 \% \text { of inhibitory activity ( } 50 \% \\
\text { inhibition was not determined) }\end{array}$ & Acarbose & $(76)$ \\
\hline & $\begin{array}{l}\text { Salix gracilistyla Miq. } \\
\text { (Salicaceae) }\end{array}$ & $\begin{array}{l}100 \% \text { of inhibitory activity } \\
(5 \mathrm{mg} / \mathrm{mL})\end{array}$ & $\begin{array}{l}\text { Acarbose with } 50 \% \text { inhibition at } \\
5-50 \mu \mathrm{g} / \mathrm{mL}\end{array}$ & $(62)$ \\
\hline & - & $50 \%$ inhibition between $0,2-0,4 \mathrm{mM}$ & $\begin{array}{l}\text { Acarbose with } 50 \% \text { inhibition at } \\
<0,1 \mathrm{mM}\end{array}$ & $(6)$ \\
\hline $\operatorname{acacetin}(9 c)$ & - & $\begin{array}{l}14 \% \text { of inhibitory activity ( } 50 \% \\
\text { inhibition was not determined) }\end{array}$ & $\begin{array}{l}\text { Acarbose with } 99 \% \text { of maxim } \\
\text { inhibition }(50 \% \text { inhibition at } \\
0,996 \mu \mathrm{M})\end{array}$ & $(41)$ \\
\hline apigetrin $(9 d)$ & - & $50 \%$ inhibition at $<0,2 \mathrm{mM}$ & $\begin{array}{l}\text { Acarbose with } 50 \% \text { inhibition at } \\
<0,1 \mathrm{mM}\end{array}$ & $(6)$ \\
\hline lonicerin $(9 e)$ & $\begin{array}{l}\text { Lonicera japonica Thunb. } \\
\text { (Caprifoliaceae) }\end{array}$ & $\begin{array}{l} \pm 55 \% \text { of inhibitory activity } \\
(5 \mathrm{mg} / \mathrm{mL})\end{array}$ & $\begin{array}{l}\text { Acarbose with } 50 \% \text { inhibition at } \\
5-50 \mu \mathrm{g} / \mathrm{mL}\end{array}$ & $(62)$ \\
\hline rhoifolin (9f) & $\begin{array}{l}\text { Lonicera japonica Thunb. } \\
\text { (Caprifoliaceae) }\end{array}$ & $\begin{array}{l} \pm 60 \% \text { of inhibitory activity } \\
(5 \mathrm{mg} / \mathrm{mL})\end{array}$ & $\begin{array}{l}\text { Acarbose with } 50 \% \text { inhibition at } \\
5-50 \mu \mathrm{g} / \mathrm{mL}\end{array}$ & $(62)$ \\
\hline diosmetin $(10 a)$ & - & $\begin{array}{l}19 \% \text { of inhibitory activity (50\% } \\
\text { inhibition was not determined) }\end{array}$ & $\begin{array}{l}\text { Acarbose with } 99 \% \text { of maxim } \\
\text { inhibition }(50 \% \text { inhibition at } \\
0,996 \mu \mathrm{M})\end{array}$ & $(41)$ \\
\hline genkwanin $(10 b)$ & - & $\begin{array}{l}17 \% \text { of inhibitory activity ( } 50 \% \\
\text { inhibition was not determined) }\end{array}$ & $\begin{array}{l}\text { Acarbose with } 99 \% \text { of maxim } \\
\text { inhibition }(50 \% \text { inhibition at } \\
0,996 \mu \mathrm{M})\end{array}$ & $(41)$ \\
\hline scutellarein $(11 a)$ & - & $\begin{array}{l}98 \% \text { of inhibitory activity }(50 \% \\
\text { inhibition at } 9,64 \mu \mathrm{M})\end{array}$ & $\begin{array}{l}\text { Acarbose with } 99 \% \text { of maxim } \\
\text { inhibition }(50 \% \text { inhibition at } \\
0,996 \mu \mathrm{M})\end{array}$ & $(41)$ \\
\hline eupafolin $(11 b)$ & - & $\begin{array}{l}99 \% \text { of inhibitory activity }(50 \% \\
\text { inhibition at } 48 \mu \mathrm{M})\end{array}$ & $\begin{array}{l}\text { Acarbose with } 99 \% \text { of maxim } \\
\text { inhibition }(50 \% \text { inhibition at } \\
0,996 \mu \mathrm{M})\end{array}$ & $(41)$ \\
\hline Bilobetin (12) & $\begin{array}{l}\text { Ginkgo biloba } \mathrm{L} . \\
\text { (Ginkgoaceae) }\end{array}$ & $\begin{array}{l} \pm 25 \% \text { of inhibitory activity } \\
(5 \mathrm{mg} / \mathrm{mL})\end{array}$ & $\begin{array}{l}\text { Acarbose with } 50 \% \text { inhibition at } \\
5-50 \mu \mathrm{g} / \mathrm{mL}\end{array}$ & $(62)$ \\
\hline \multicolumn{5}{|l|}{ Flavanone } \\
\hline naringenin $(13 a)$ & - & $\begin{array}{l}26 \% \text { of inhibitory activity ( } 50 \% \\
\text { inhibition was not determined) }\end{array}$ & $\begin{array}{l}\text { Acarbose with } 99 \% \text { of maxim } \\
\text { inhibition }(50 \% \text { inhibition at } \\
0,996 \mu \mathrm{M})\end{array}$ & $(41)$ \\
\hline hesperetin $(13 b)$ & - & $39 \%$ of inhibitory activity $(50 \%$ & Acarbose with $99 \%$ of maxim & $(41)$ \\
\hline
\end{tabular}




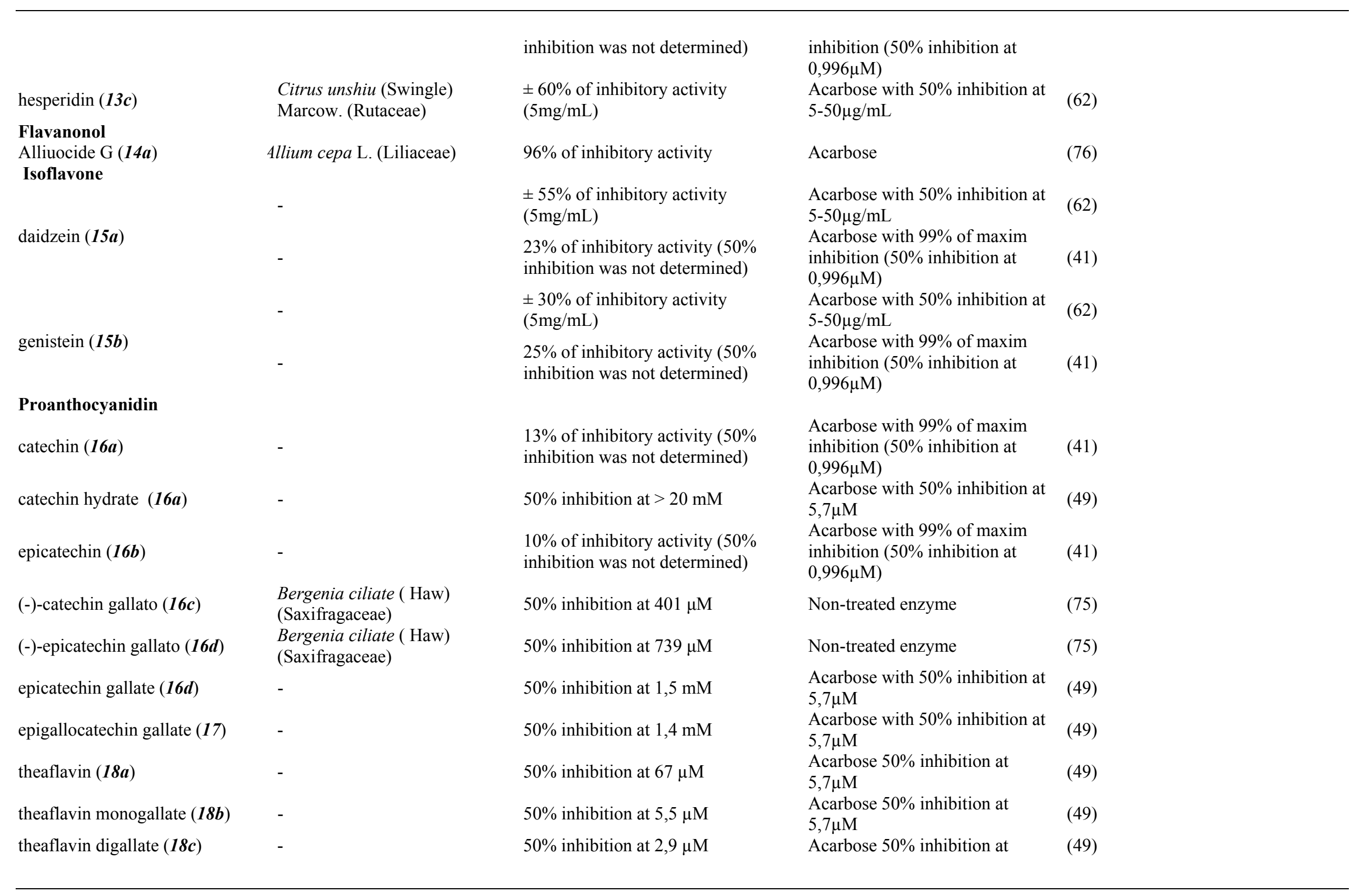




\section{Others}

2-(3,4-Dihydroxybenzoyl)-

2,4,6-trihydroxy-3 $(2 H)$ -

benzofuranone (19)

Aceronidin (20)

\section{Tannin}

"Aleppo tannin" (Gallotanin) (21)

Pedunculagin $(22 a)$

1( )-O-galloyl pedunculagin (22b)

$1(\alpha)$ - galloyl pedunculagin

(22b)

strictinin (23a)

sanguiin H5 (23b)

roshenin B (1-desgalloyl sanguiin H6 (23c)

sanguiin $\mathrm{H} 2(23 d)$

sanguiin $\mathrm{H} 10(23 e)$
Allium cepa L. (Liliaceae)

Malpighia emarginata DC. (Malpighiaceae)

"Gall nut"

Rubus suavissimus S. LEE (Rosaceae)

Rubus suavissimus S. LEE

(Rosaceae)

Rubus suavissimus $\mathrm{S}$. LEE

(Rosaceae)

Rubus suavissimus S. LEE

(Rosaceae)

Rubus suavissimus $\mathrm{S}$. LEE

(Rosaceae)

Rubus suavissimus S. LEE

(Rosaceae)

Rubus suavissimus S. LEE

(Rosaceae)

Rubus suavissimus S. LEE (Rosaceae)

\section{$5,7 \mu \mathrm{M}$}

$88 \%$ of inhibitory activity

Acarbose

$34 \%$ of inhibitory activity $(50 \%$ inhibition at $820 \mu \mathrm{M}$ )

Non-treated enzyme

Dissociation

Acarbose with dissociation constants of the inhibitor

constants of the inhibitor containing containing complexes EI $\left(K_{\mathrm{EI}}\right)$

$\begin{array}{ll}\begin{array}{l}\text { complexes EI }\left(K_{\mathrm{EI}}\right) 0,82 \mu \mathrm{g} \mathrm{mL}^{-1} \text { vs } \\ \text { dissociation }\end{array} & \begin{array}{l}0,45 \mu \mathrm{g} \mathrm{mL}^{-1} \text { vs dissociation } \\ \text { constants of the inhibitor }\end{array}\end{array}$ dissociation

constants of the inhibitor containing containing complexes ESI $\left(K_{\mathrm{ESI}}\right)$ complexes ESI $\left(K_{\mathrm{ESI}}\right) 3,32 \mu \mathrm{g} \mathrm{mL}^{-1} \quad 0,065 \mu \mathrm{gmL}^{-1}$

theaflavin-

inhibition
$14 \%$ of inhibitory activity $\quad 3,3$-di- $O$-gallate with $83 \%$ of inhibition

theaflavin-

$56 \%$ of inhibitory activity $\quad 3,3$-di- $O$-gallate with $83 \%$ of

inhibition

theaflavin-

$36 \%$ of inhibitory activity

3,3_-di-O-gallate with $83 \%$ of

inhibition

theaflavin-

$52 \%$ of inhibitory activity

3,3_-di-O-gallate with $83 \%$ of

inhibition

$56 \%$ of inhibitory activity

theaflavin-

3,3_-di-O-gallate with $83 \%$ of inhibition

theaflavin-3,3_-di-O-gallate

with $83 \%$ of inhibition

theaflavin-

3,3 -di- $O$-gallate with $83 \%$ of

inhibition

theaflavin-

3,3 -di- $O$-gallate with $83 \%$ of

$23 \%$ of inhibitory activity 
sanguiin H11 (23f)

lambertianin A (23g)

sanguiin H6 (23h)

rubusuaviin A $(24 a)$

rubusuaviin B (24b)

rubusuaviin $\mathrm{C}(24 c)$

rubusuaviin D $(24 d)$

rubusuaviin $\mathrm{E}(24 \mathrm{e})$

rubusuaviin F (24f)

Tannic acid (25)

\section{Cinnamic acid derivatives}

chlorogenic acid (26)

isochlorogenic acid (27)

rosmarinic acid (28)
Rubus suavissimus S. LEE

(Rosaceae)

Rubus suavissimus S. LEE (Rosaceae)

Rubus suavissimus S. LEE

(Rosaceae)

Rubus suavissimus S. LEE

(Rosaceae)

Rubus suavissimus S. LEE

(Rosaceae)

Rubus suavissimus S. LEE

(Rosaceae)

Rubus suavissimus S. LEE (Rosaceae)

Rubus suavissimus S. LEE (Rosaceae)

Rubus suavissimus S. LEE (Rosaceae)

(1)

theaflavin-

3,3 -di-O-gallate with $83 \%$ of

inhibition

theaflavin-

3,3 -di-O-gallate with $83 \%$ of

inhibition

theaflavin-3,3 -di- $O$-gallate

with $83 \%$ of inhibition

theaflavin-3,3_-di-O-gallate

with $83 \%$ of inhibition

$60 \%$ of inhibitory activity

theaflavin-3,3_-di-O-gallate

with $83 \%$ of inhibition

theaflavin

3,3-di-O-gallate with $83 \%$ of

inhibition

theaflavin-3,3-di- $O$-gallate with

$83 \%$ of inhibition

theaflavin-

3,3-di-O-gallate with $83 \%$ of

inhibition

theaflavin-3,3-di- $O$-gallate with

$83 \%$ of inhibition

Acarbose with 50\% inhibition at

$<0,1 \mathrm{mM}$

$50 \%$ inhibition at $<0,2 \mathrm{mM}$

Dissociation constants of the

inhibitor containing complexes EI

$\left(K_{\mathrm{EI}}\right)$ between $8-9 \mu \mathrm{g} \mathrm{mL}^{-1} v s$ $-$

dissociation constants of the

inhibitor containing complexes ESI

$\left(K_{\mathrm{ESI}}\right)$ between $45-49 \mu \mathrm{gmL}^{-1}$

$50 \%$ inhibition between 1,4-1,6mM Acarbose with 50\% inhibition at

$<0,1 \mathrm{mM}$

$50 \%$ inhibition between $0,6-0,8 \mathrm{mM}$

Acarbose with $50 \%$ inhibition at

$<0,1 \mathrm{mM}$

$85 \%$ of inhibitory activity 


\begin{tabular}{|c|c|c|c|c|}
\hline & - & $50 \%$ inhibition between $1,4-1,6 \mathrm{mM}$ & $\begin{array}{l}\text { Acarbose with } 50 \% \text { inhibition at } \\
<0,1 \mathrm{mM}\end{array}$ & $(6)$ \\
\hline esculin (29) & - & $50 \%$ inhibition between $1,4-1,6 \mathrm{mM}$ & $\begin{array}{l}\text { Acarbose with } 50 \% \text { inhibition at } \\
<0,1 \mathrm{mM}\end{array}$ & $(6)$ \\
\hline \multicolumn{5}{|l|}{ Terpenes } \\
\hline Squalene (33) & - & $30 \%$ of inhibitory activity & \multirow{2}{*}{$\begin{array}{l}\text { Non-treated enzyme } \\
\alpha \text {-Amylase inhibitor from wheat } \\
\text { seed Triticum aestivum }\end{array}$} & $(31)$ \\
\hline Lupeol (34) & - & $\pm 50 \%$ of inhibitory activity & & (70) \\
\hline $\begin{array}{l}\text { 3-O-[(9Z)-9exadec-9-enoyl]- - } \\
\text { amyrin (35) }\end{array}$ & $\begin{array}{l}\text { Spondias mombin L. } \\
\text { (Anacardiaceae) }\end{array}$ & $57 \%$ of inhibitory activity & Acarbose & (79) \\
\hline oleanolic acid (36a) & - & $\pm 55 \%$ of inhibitory activity & $\begin{array}{l}\alpha \text {-Amylase inhibitor from wheat } \\
\text { seed Triticum aestivum }\end{array}$ & $(70)$ \\
\hline ursolic acid (36b) & - & $\pm 87,5 \%$ of inhibitory activity & $\begin{array}{l}\alpha \text {-Amylase inhibitor from wheat } \\
\text { seed Triticum aestivum }\end{array}$ & $(70)$ \\
\hline $\begin{array}{l}\text { mixture of lambertianin C (23i), } \\
\text { Sanguiin H10 (23e), and } \\
\text { Sanguiin H6 (23h) }\end{array}$ & $\begin{array}{l}\text { Rubus idaeus L. variety Glen } \\
\text { Ample (Rosaceae) }\end{array}$ & $\pm 75 \%$ of inhibitory activity & $\begin{array}{l}\text { green tea with } \pm 99 \% \text { of maxim } \\
\text { inhibition }\end{array}$ & $(80)$ \\
\hline $\begin{array}{l}\text { Mixture of gallic acid (2), } \\
\text { proto-catechuic acid (30), } \\
\text { caffeic acid (32a), ellagic acid } \\
(31), \text { ferulic acid }(32 b), \\
\text { quercetin }(3 a) \text { and kaempferol } \\
(3 e)\end{array}$ & $\begin{array}{l}\text { Centratherum anthelminticum } \\
\text { ( L.) Kuntze (Asteraceae) }\end{array}$ & $\begin{array}{l}90 \% \text { of inhibitory activity ( } 50 \% \\
\text { inhibition at } 185 \mu \mathrm{g} \text { ) }\end{array}$ & $\begin{array}{l}\text { Acarbose with } 85 \% \text { of maxim } \\
\text { inhibition }(50 \% \text { inhibition at } \\
17 \mu \mathrm{g})\end{array}$ & $(81)$ \\
\hline $\begin{array}{l}\text { Isomeric mixture of oleanolic } \\
(36 a) \text { and ursolic acid }(36 b)\end{array}$ & $\begin{array}{l}\text { Phyllanthus amarus } \\
\text { Schumach. \& Thonn. } \\
\text { (Euphorbiaceae) }\end{array}$ & $\begin{array}{l} \pm 65 \% \text { of inhibitory activity }(50 \% \\
\text { inhibition at } 2,01 \mu \mathrm{g})\end{array}$ & $\begin{array}{l}\alpha \text {-Amylase inhibitor from wheat } \\
\text { seed Triticum aestivum }\end{array}$ & $(70)$ \\
\hline $\begin{array}{l}\text { Mixture of betulinic acid (37) } \\
\text { and } 3,5,7,4 \text { - tetrahydroxy } \\
\text { flavanone }(\mathbf{1 4 b})\end{array}$ & $\begin{array}{l}\text { Syzygium cumini L. } \\
\text { (Myrtaceae) }\end{array}$ & $98 \%$ of inhibitory activity & Not determined & $(29)$ \\
\hline
\end{tabular}




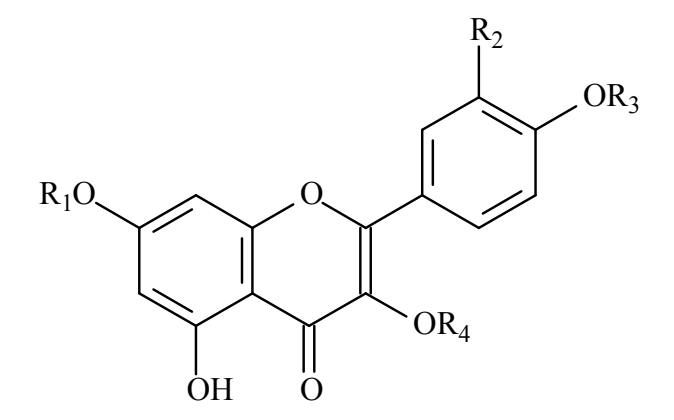

$\begin{array}{llllll} & \mathrm{R}_{1} & \mathrm{R}_{2} & \mathrm{R}_{3} & \mathrm{R}_{4} & \\ 3 \mathrm{a} & \mathrm{H} & \mathrm{OH} & \mathrm{H} & \mathrm{H} & \text { quercetin } \\ 3 \mathrm{~b} & \mathrm{CH}_{3} & \mathrm{OH} & \mathrm{CH}_{3} & \mathrm{OCH}_{3} & \\ 3 \mathrm{c} & \mathrm{H} & \mathrm{OH} & \mathrm{H} & \text { rham } & \text { quercetrin } \\ 3 \mathrm{~d} & \mathrm{H} & \mathrm{OH} & \mathrm{H} & \text { rham-glu } \\ 3 \mathrm{e} & \mathrm{H} & \mathrm{H} & \mathrm{H} & \mathrm{H} & \text { kaempfin } \\ 3 \mathrm{f} & \mathrm{H} & \mathrm{H} & \mathrm{H} & \mathrm{CH}_{3} & \\ 3 \mathrm{~g} & \mathrm{CH}_{3} & \mathrm{H} & \mathrm{H} & \mathrm{CH}_{3} & \\ 3 \mathrm{~h} & \mathrm{CH}_{3} & \mathrm{H} & \mathrm{CH}_{3} & \mathrm{CH}_{3} & \\ 3 \mathrm{i} & \mathrm{H} & \mathrm{H} & \mathrm{H} & \text { glu } & \text { astragalin } \\ 3 \mathrm{j} & \mathrm{H} & \mathrm{OH} & \mathrm{H} & \text { gal } & \text { hyperin }\end{array}$

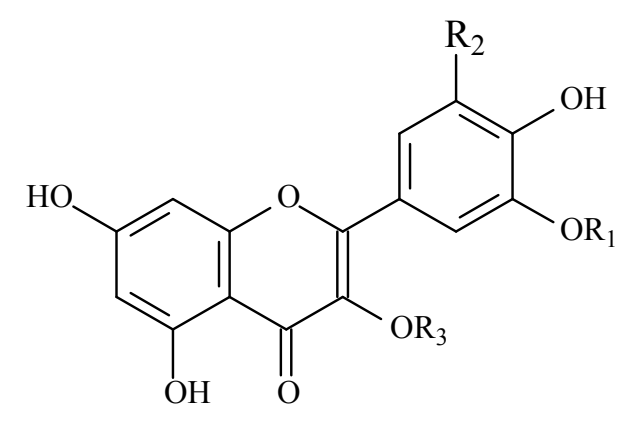

$\begin{array}{lllll} & \mathrm{R}_{1} & \mathrm{R}_{2} & \mathrm{R}_{3} & \\ 4 \mathrm{a} & \mathrm{CH}_{3} & \mathrm{H} & \mathrm{H} & \text { isorhamnetin } \\ 4 \mathrm{~b} & \mathrm{CH}_{3} & \mathrm{H} & \text { rham-glu } \\ 4 \mathrm{c} & \mathrm{H} & \mathrm{H} & \mathrm{H} & \text { fisetin } \\ 4 \mathrm{~d} & \mathrm{H} & \mathrm{OH} & \mathrm{H} & \text { myricetin }\end{array}$

Figure 2. Flavonoids presenting $\alpha$-amylase inhibition activity 
<smiles>O=C1c2c(O)cc(O)cc2OC2(c3ccc(O)c(O)c3)c3ccc(-c4oc5cc(O)cc(O)c5c(=O)c4O)cc3OC12O</smiles>

5a $\mathrm{H}$

$5 \mathrm{~b}$ glu<smiles>O=c1c(O)c(-c2ccc(O)c(O)c2)oc2cc(O)c(O)c(O)c12</smiles>

6 quercetagetin

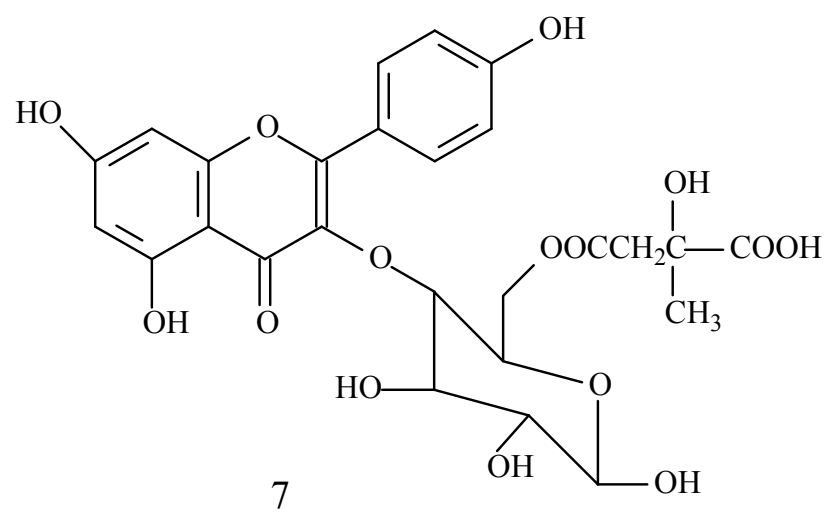

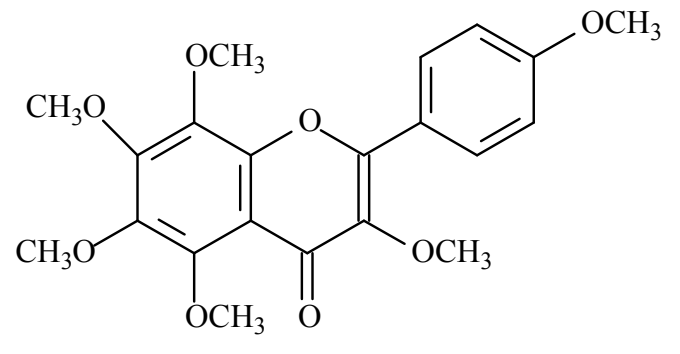

8 auranetin-5-methylether

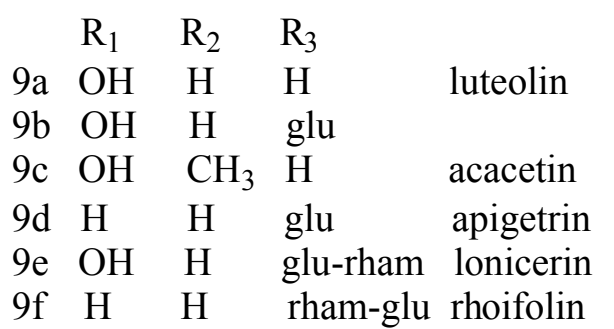

if $\mathrm{H} \quad \mathrm{H}$ rham-glu rhoifolin

Figure 2. Flavonoids presenting $\alpha$-amylase inhibition activity (..... Continued) 


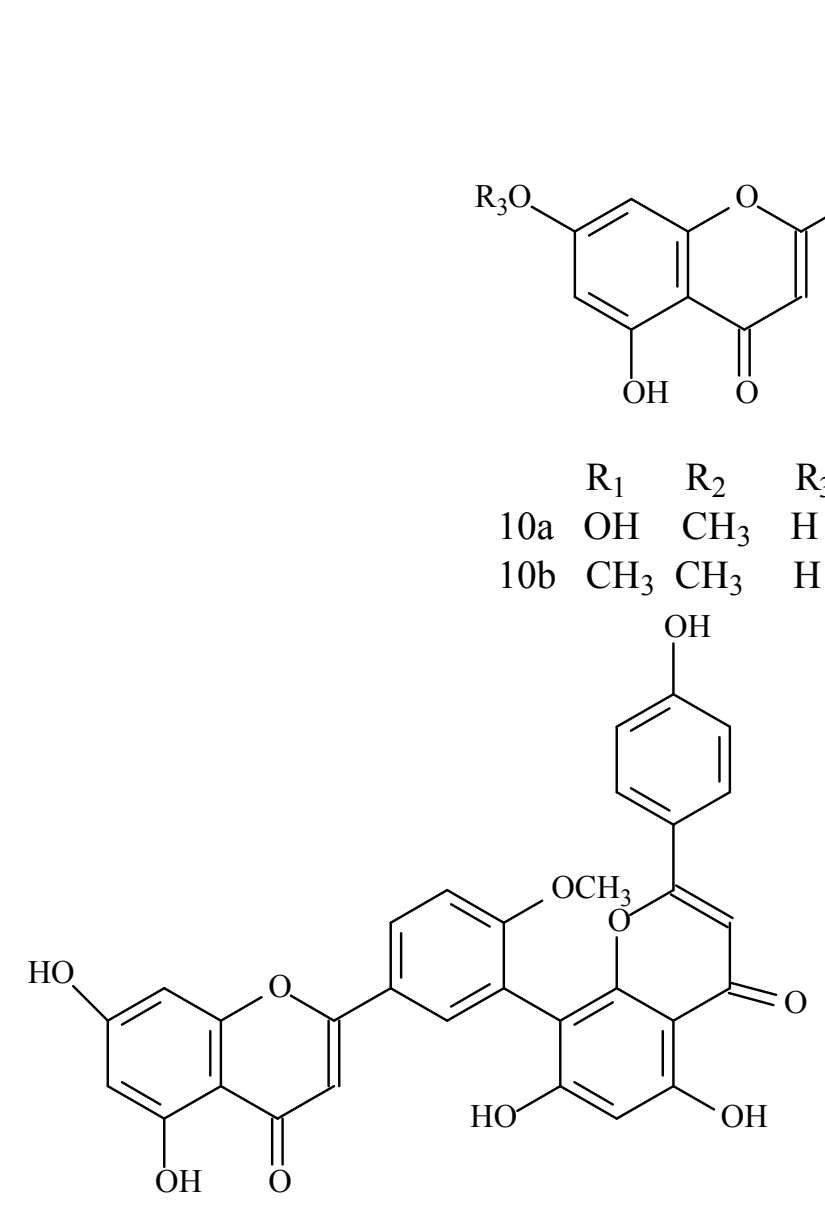

12 bilobetin<smiles>[R20]Oc1ccc(-c2cc(=O)c3c(O)c([R6])c([R20])cc3o2)cc1[R4]</smiles>

$\begin{array}{llll}\mathrm{R}_{1} & \mathrm{R}_{2} & \mathrm{R}_{3} & \mathrm{R}_{4}\end{array}$

$\begin{array}{llllll}11 \mathrm{a} & \mathrm{H} & \mathrm{H} & \mathrm{H} & \mathrm{H} & \text { scutellarein }\end{array}$

$\begin{array}{llllll}11 \mathrm{~b} & \mathrm{H} & \mathrm{H} & \mathrm{CH}_{3} & \mathrm{OH} \text { eupafolin }\end{array}$

10a $\quad \mathrm{OH} \quad \mathrm{CH}_{3} \quad \mathrm{H}$ diosmetin

genkwanin<smiles>[R6]Oc1cc(O)c2c(c1)O[C@H](c1ccc(O[R20])c([R])c1)CC2=O</smiles>

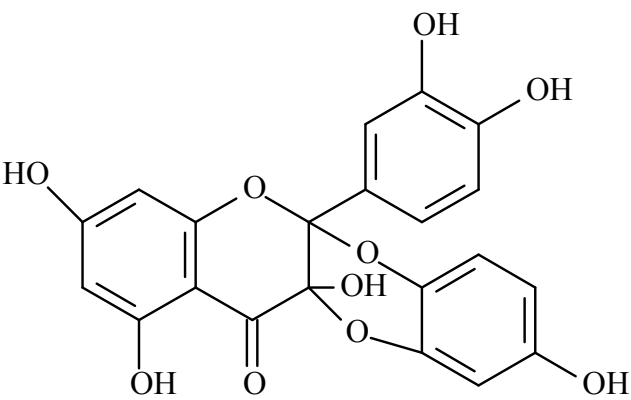

14a alliuocide $\mathrm{G}$

Figure 2. Flavonoids presenting $\alpha$-amylase inhibition activity (.... Continued) 
<smiles>O=C1c2c(O)cc(O)cc2OC(c2ccc(O)cc2)C1O</smiles>

$14 \mathrm{~b}$

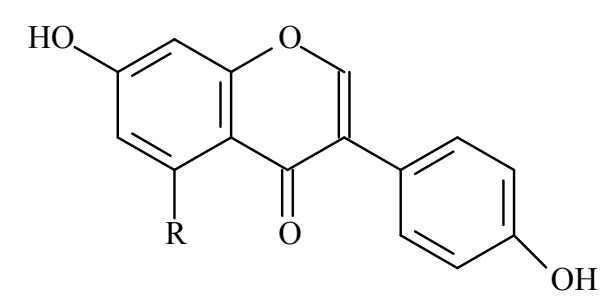

$\mathrm{R}$

15a $\mathrm{H}$ daidzein

$15 \mathrm{~b} \mathrm{OH}$ genistein<smiles>O=C(OC1Cc2c(O)cc(O)cc2O[C@@H]1c1ccc(O)c(O)c1)c1cc(O)c(O)c(O)c1</smiles>

16c …n...1 3-O-gallocatechin

$16 \mathrm{~d}-3$-O-galloylepicatechin<smiles>Oc1cc(O)c2c(c1)O[C@H](c1ccc(O)c(O)c1)[C@H](O)C2</smiles>

16a …n..." catechin

$16 \mathrm{~b} \longrightarrow$ epicatechin

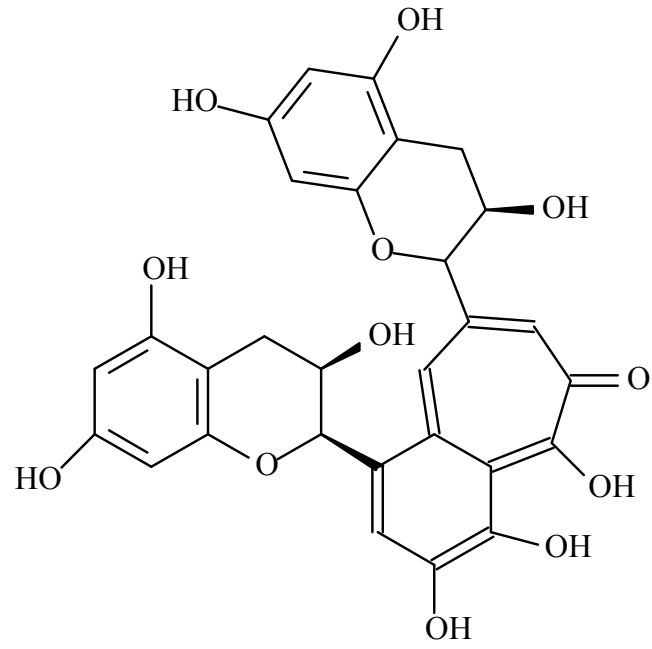

18a theaflavin

Figure 2. Flavonoids presenting $\alpha$-amylase inhibition activity (..... Continued) 


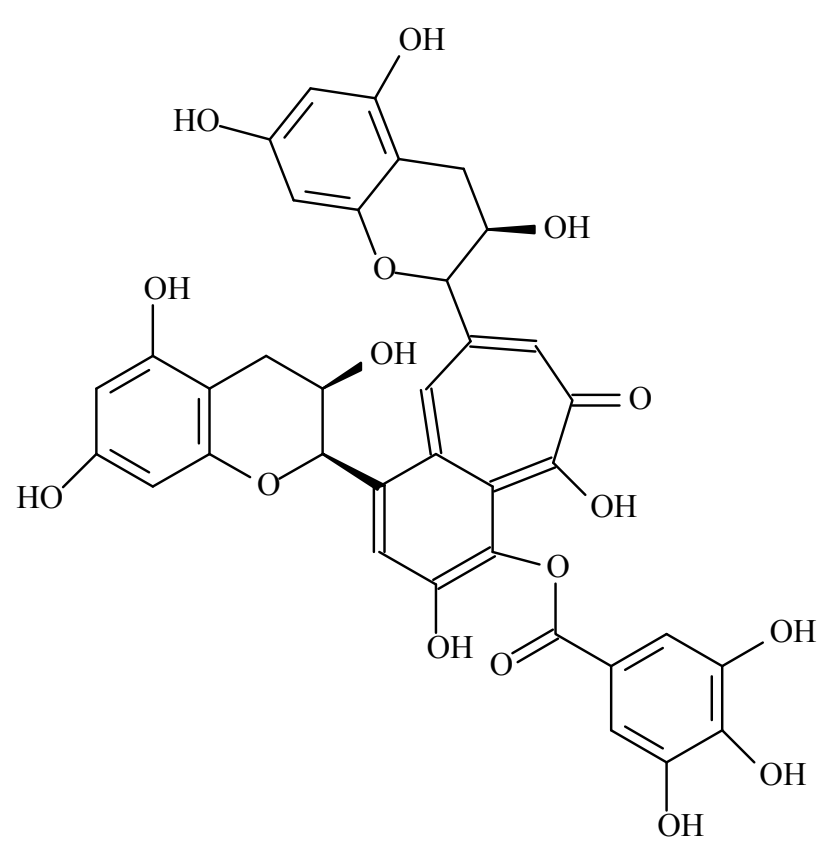

$18 \mathrm{~b}$ theaflavin monogallate

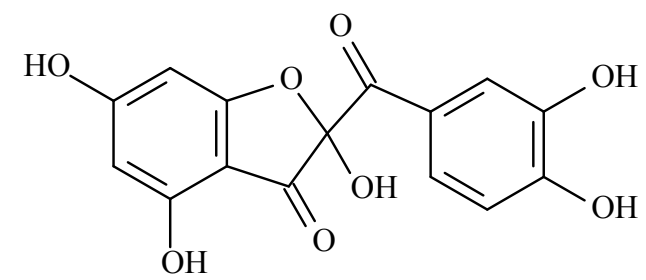

19

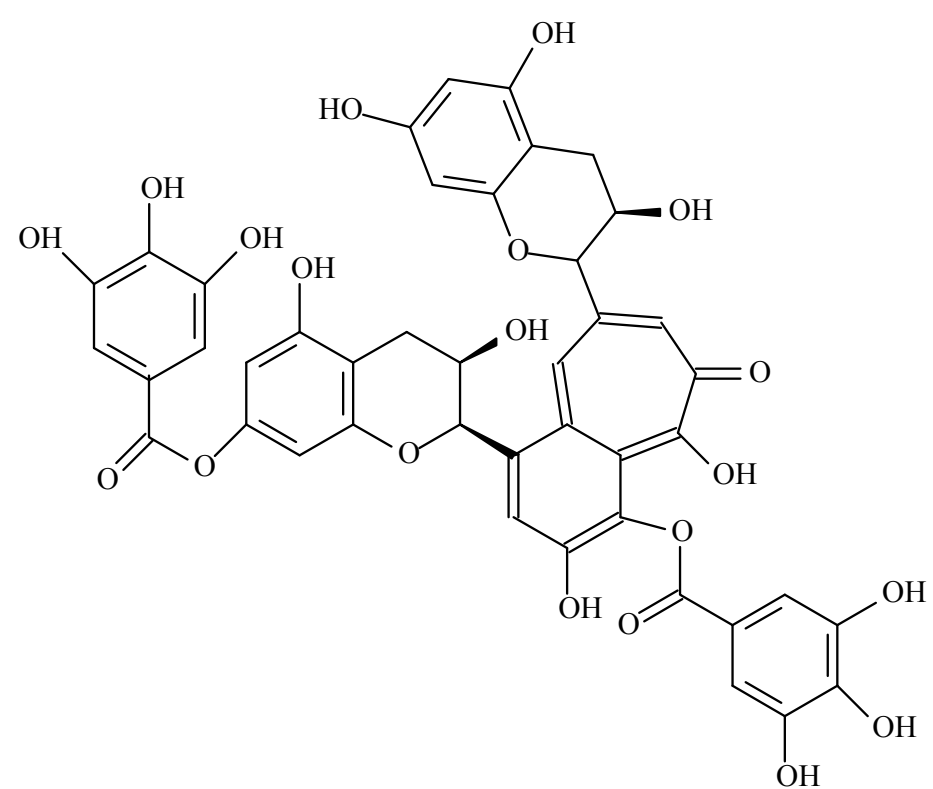

$18 \mathrm{c}$ theaflavin digallate

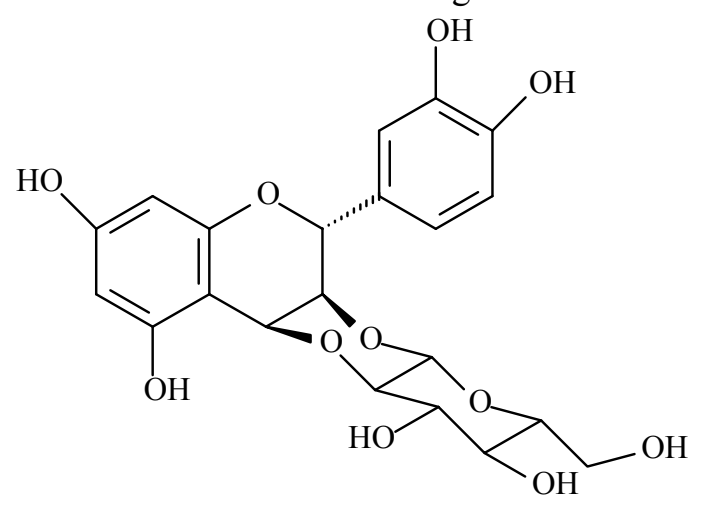

20 aceronidin

Figure 2. Flavonoids presenting $\alpha$-amylase inhibition activity (Continued) 


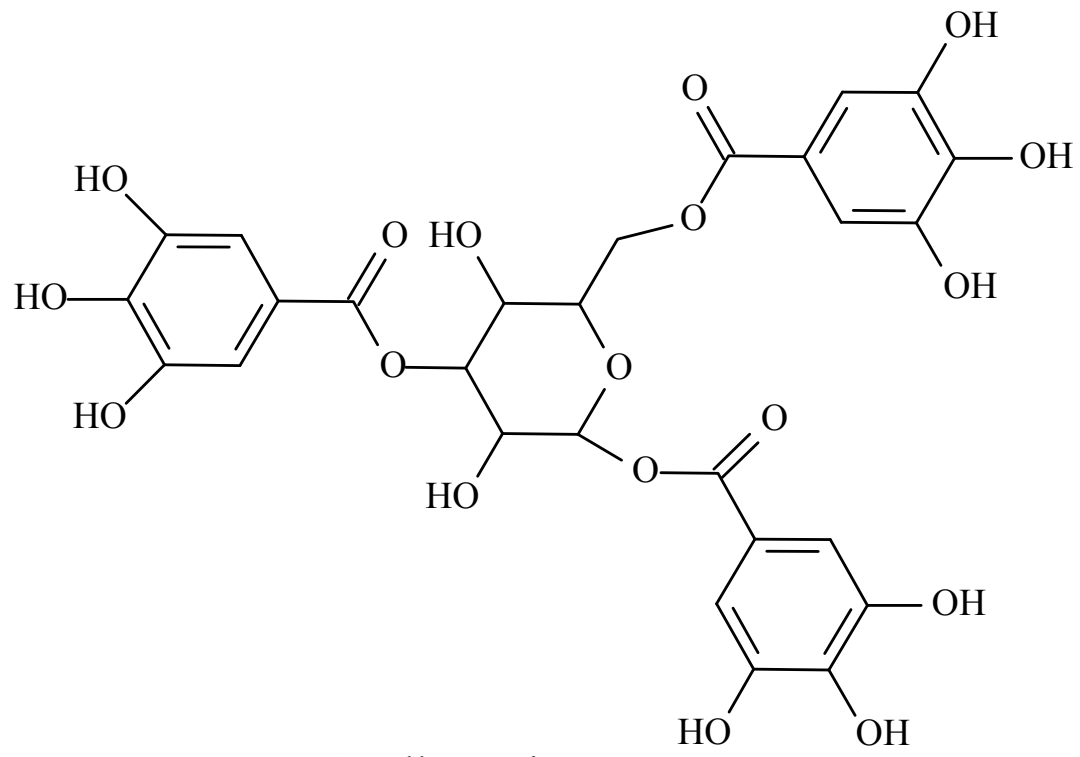

21 gallotannin

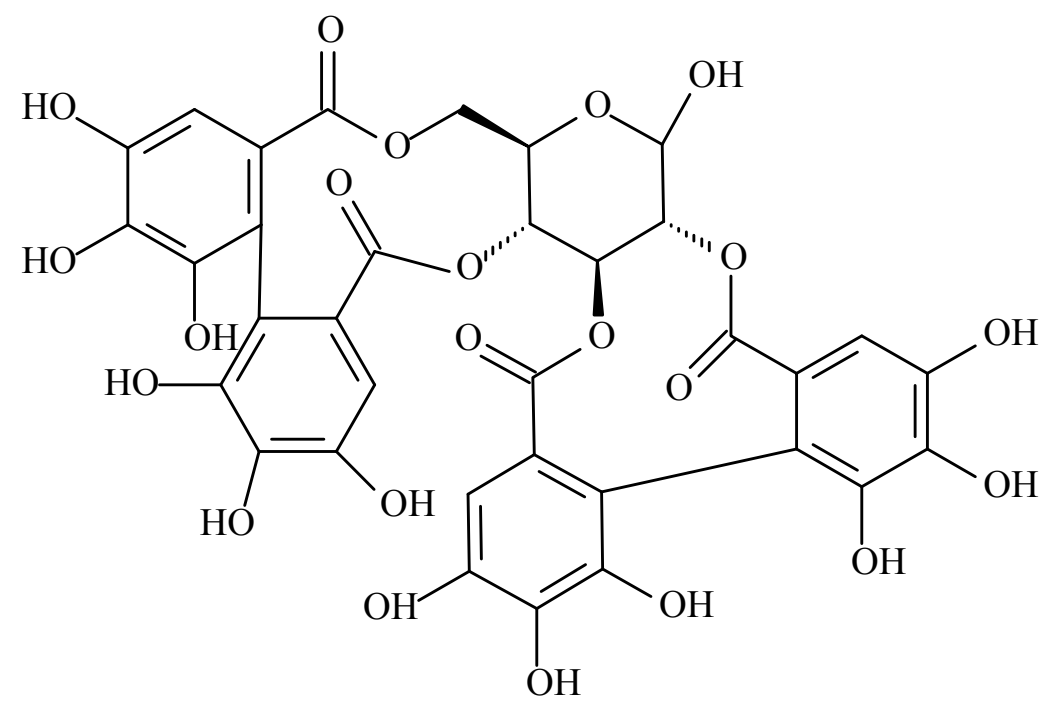

22a pedunculagin

Figure 3. Tannins presenting $\alpha$-amylase inhibition activity 


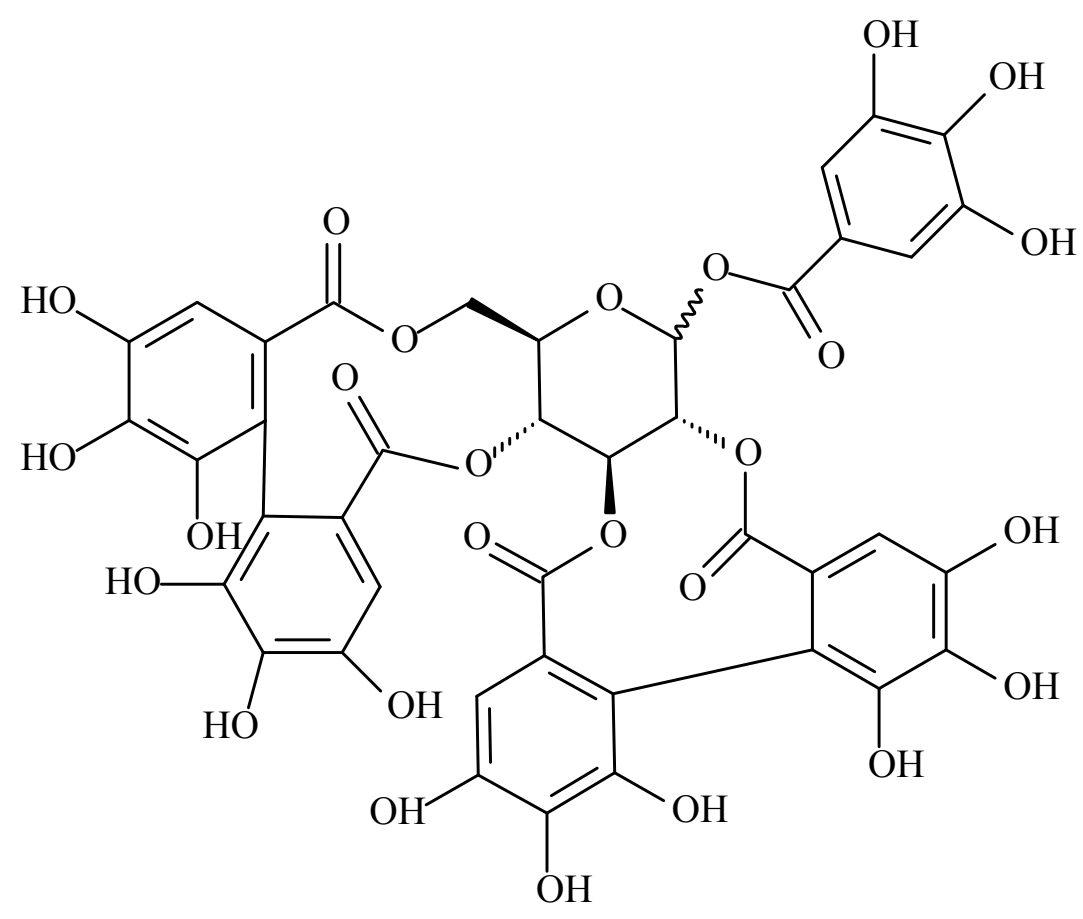

22b 1-O-galloyl pedunculagin

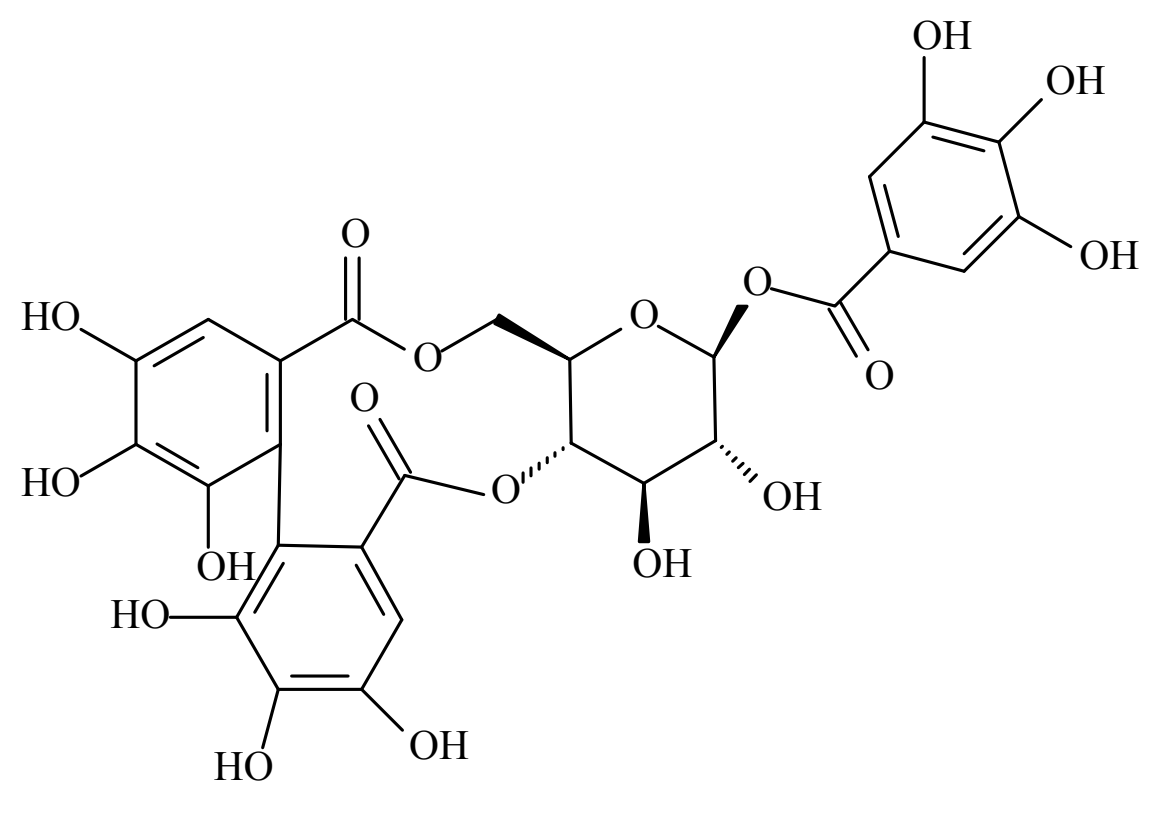

23a strictinin

Figure 3. Tannins presenting $\alpha$-amylase inhibition activity (Continued.....) 
<smiles>O=C(O[C@H]1C(OC(=O)c2cc(O)c(O)c(O)c2-c2c(O)c(O)c(O)c(O)c2O)[C@H](O)C(CO)O[C@@H]1OC(=O)c1cc(O)c(O)c(O)c1)c1cc(O)c(O)c(O)c1</smiles>

23b sanguiin $\mathrm{H} 5$

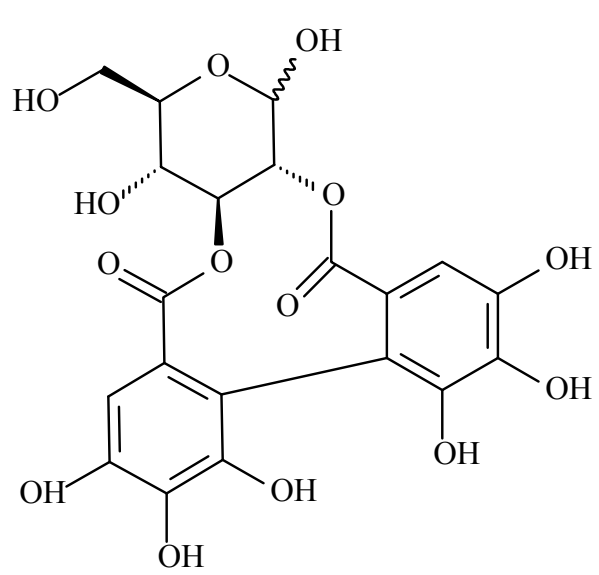

23c roshenin B

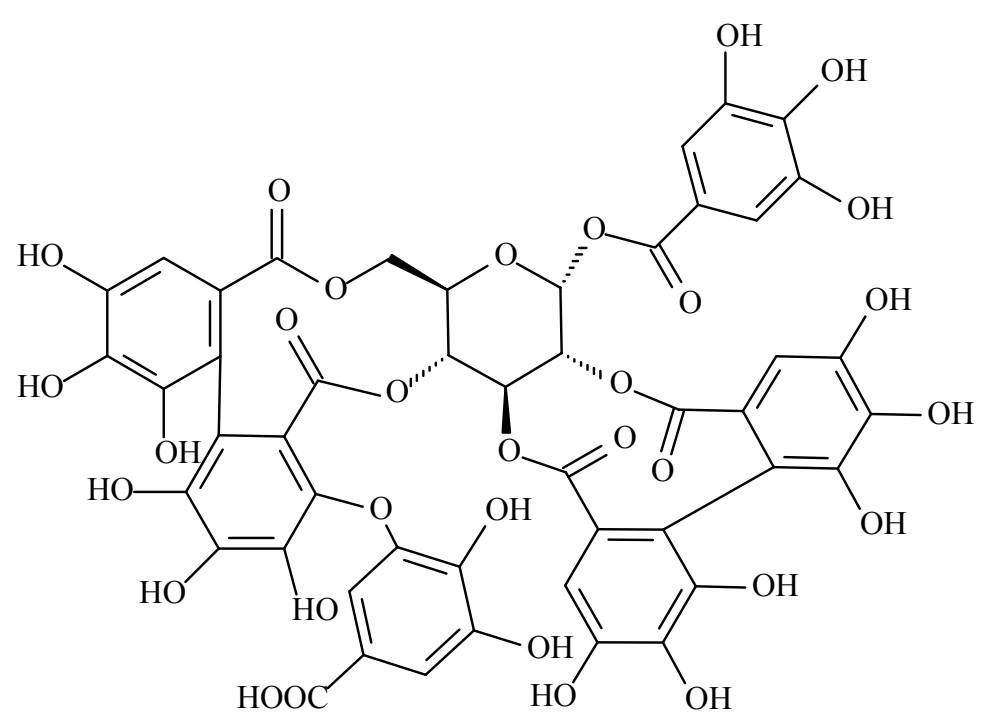

23d sanguiin $\mathrm{H} 2$

Figure 3. Tannins presenting $\alpha$-amylase inhibition activity (Continued.....) 


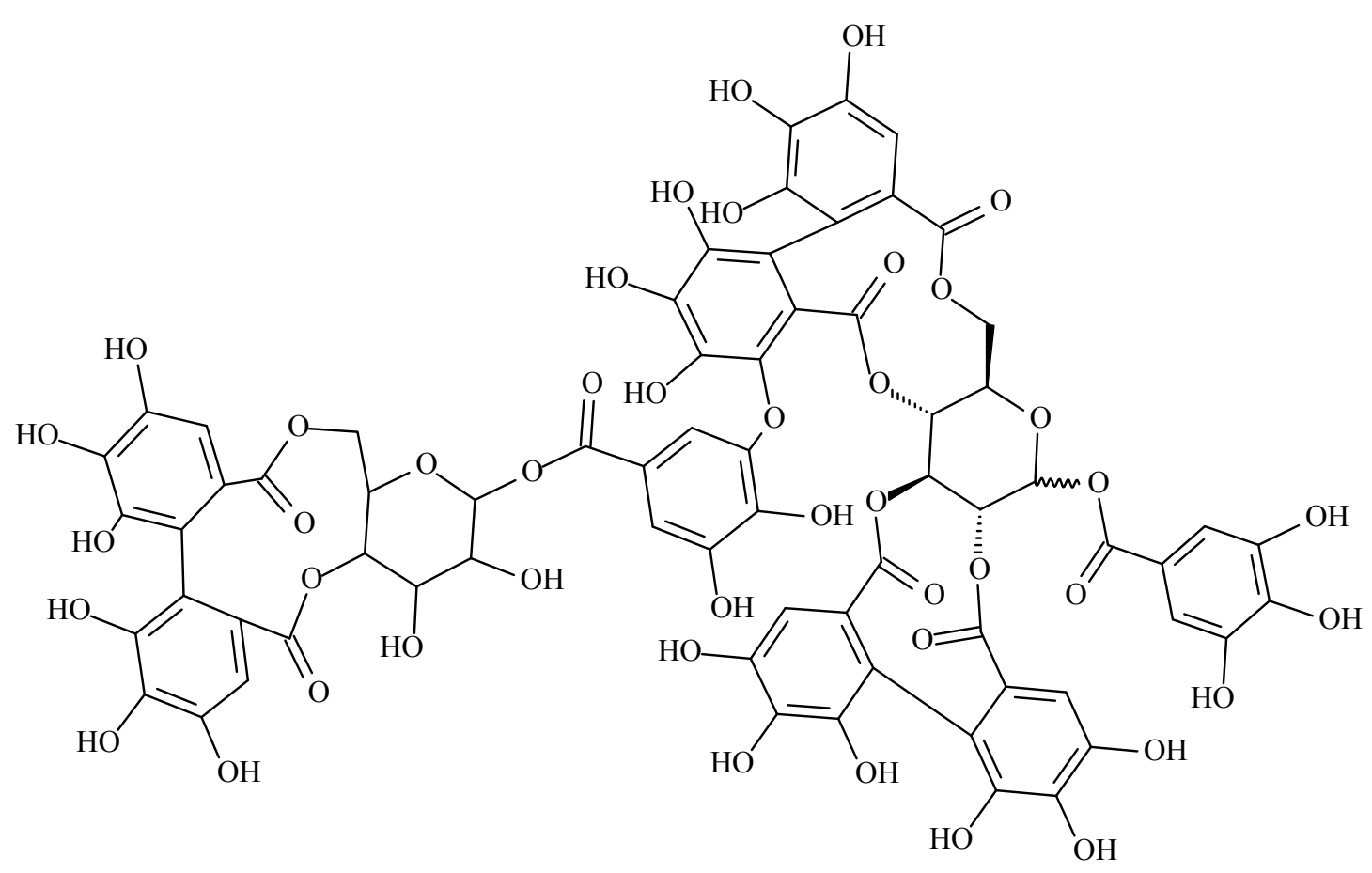

23e sanguiin $\mathrm{H} 10$

Figure 3. Tannins presenting $\alpha$-amylase inhibition activity (Continued.....) 


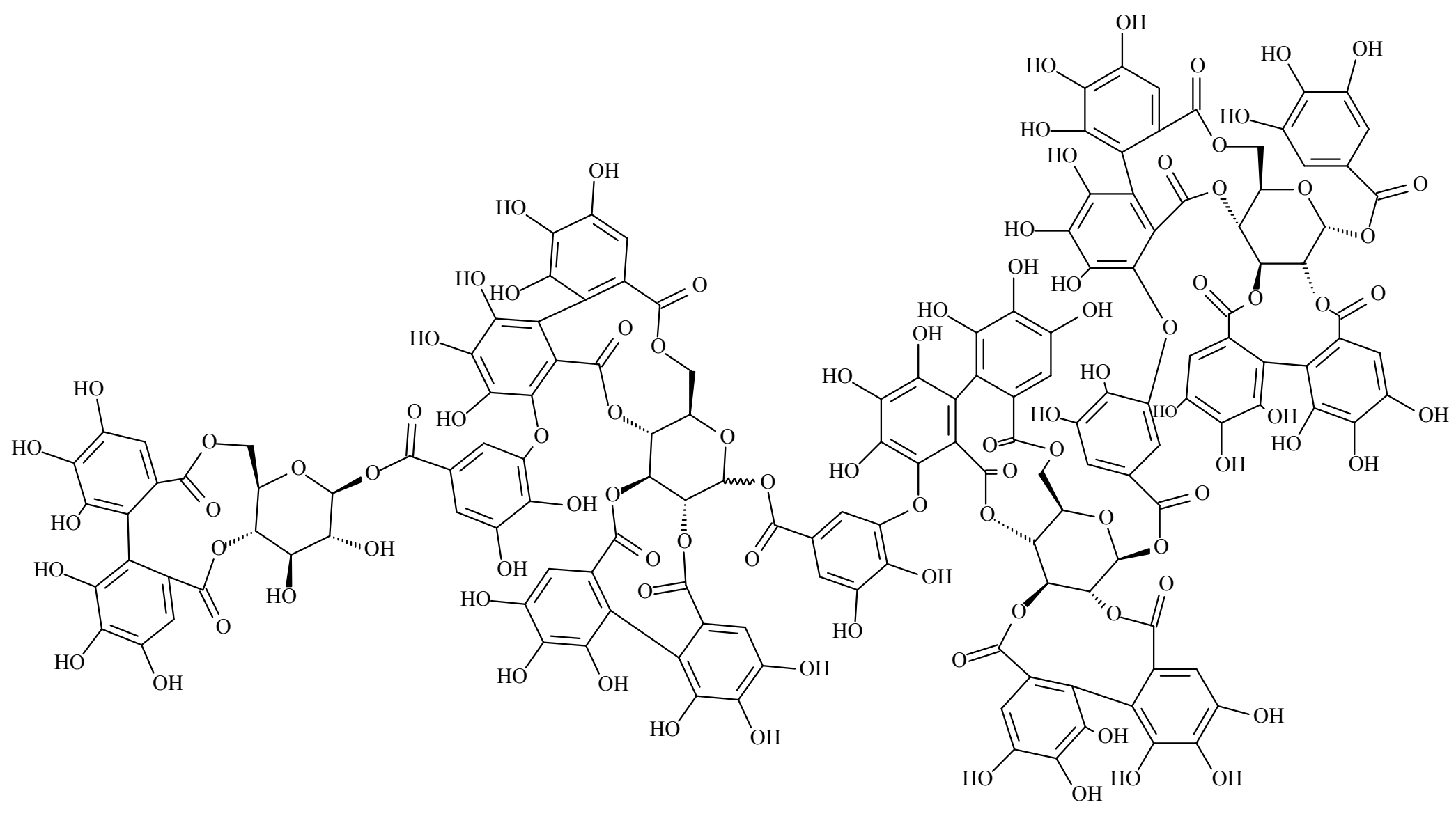

23f sanguiin H11

Figure 3. Tannins presenting $\alpha$-amylase inhibition activity (Continued.....) 


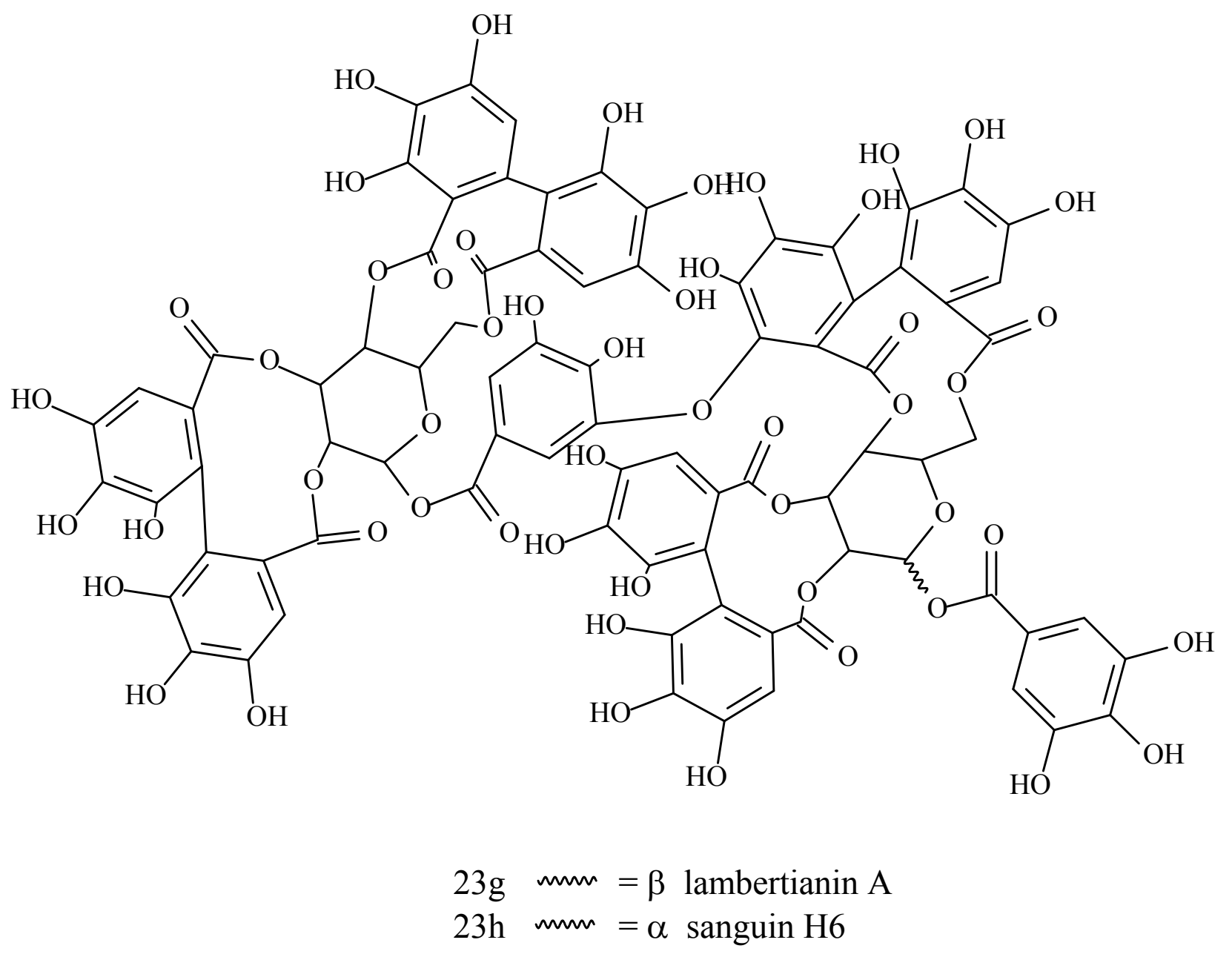

Figure 3. Tannins presenting $\alpha$-amylase inhibition activity (Continued.....) 


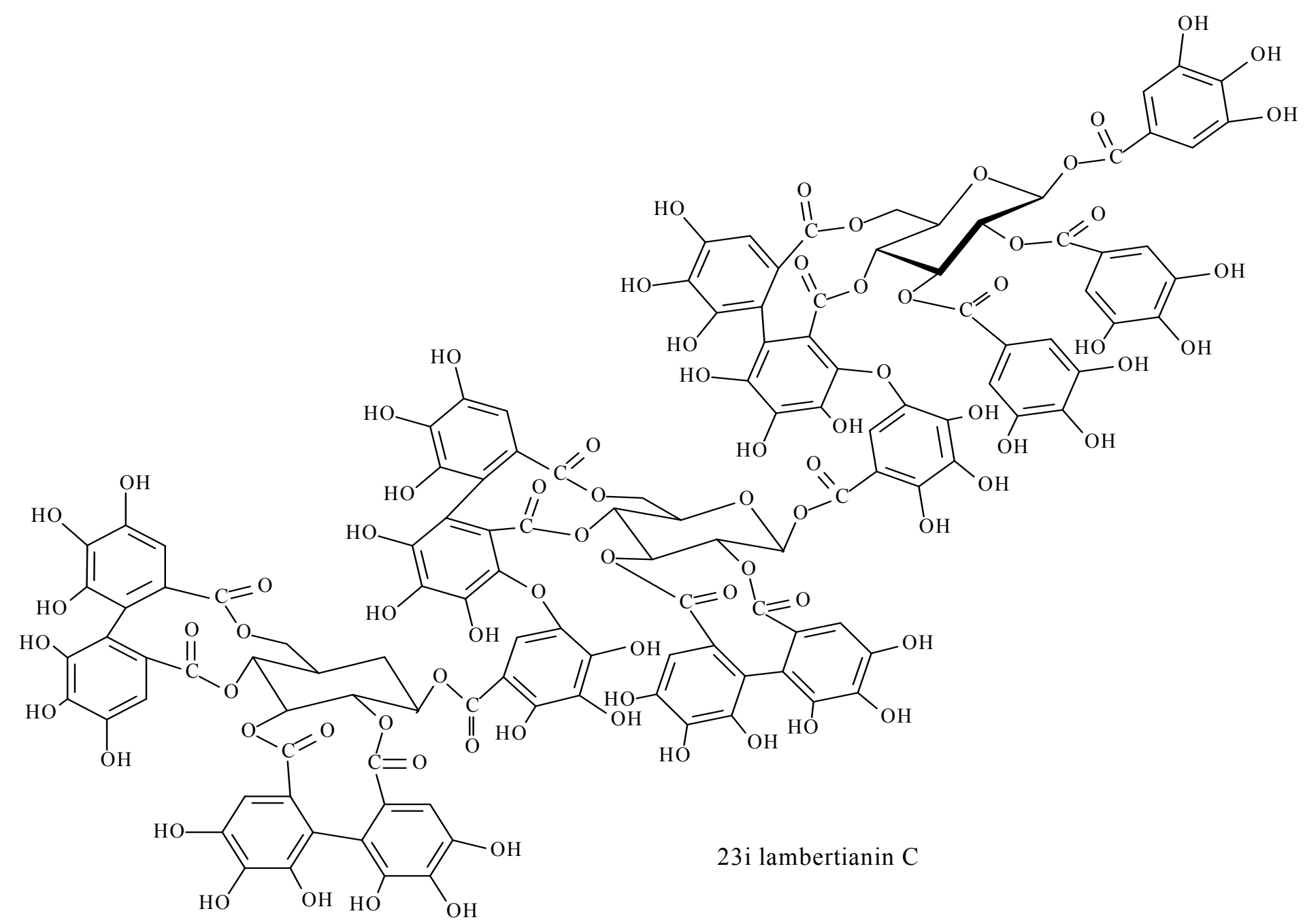

Figure 3. Tannins presenting $\alpha$-amylase inhibition activity (Continued.....) 


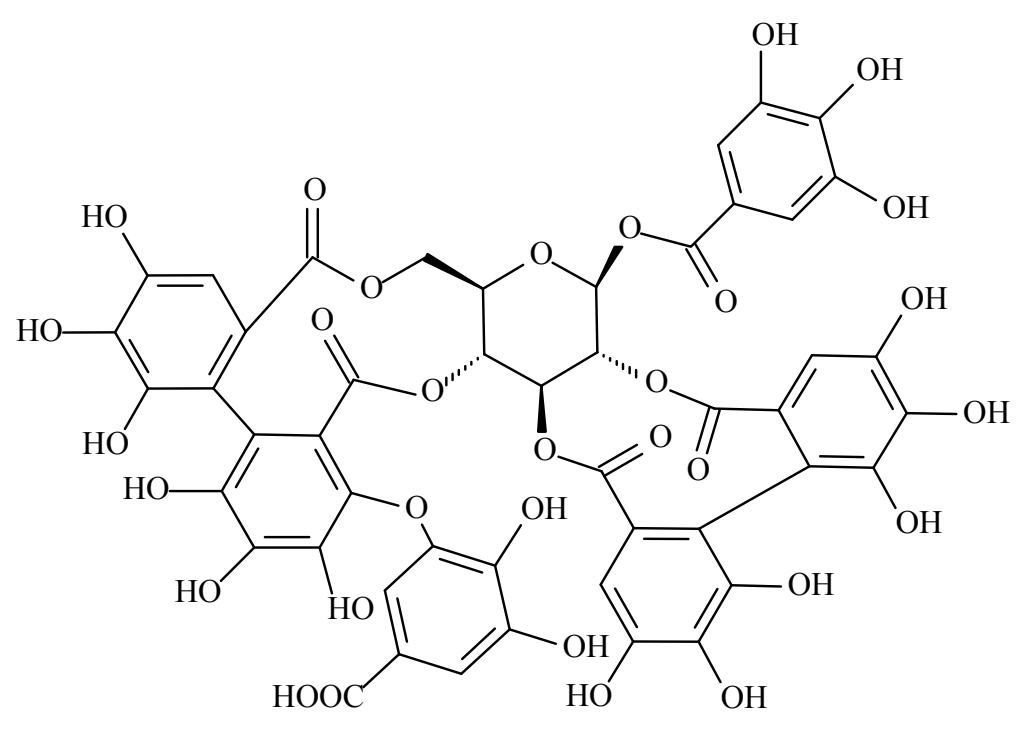

24a rubusuaviin $\mathrm{A}$

Figure 3. Tannins presenting $\alpha$-amylase inhibition activity (Continued.....) 


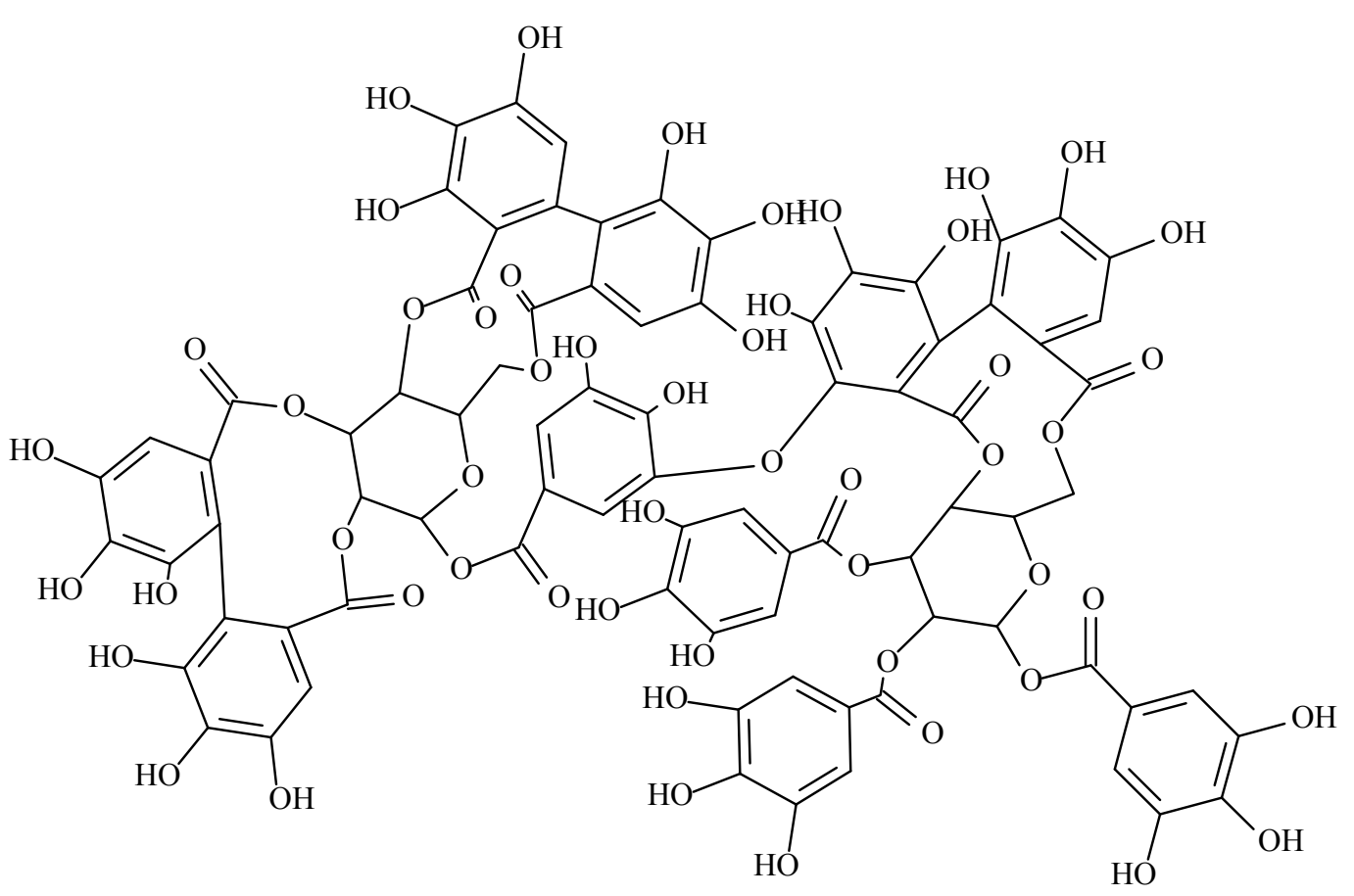

$24 \mathrm{~b}$ rubusuaviin $\mathrm{B}$

Figure 3. Tannins presenting $\alpha$-amylase inhibition activity (Continued.....) 


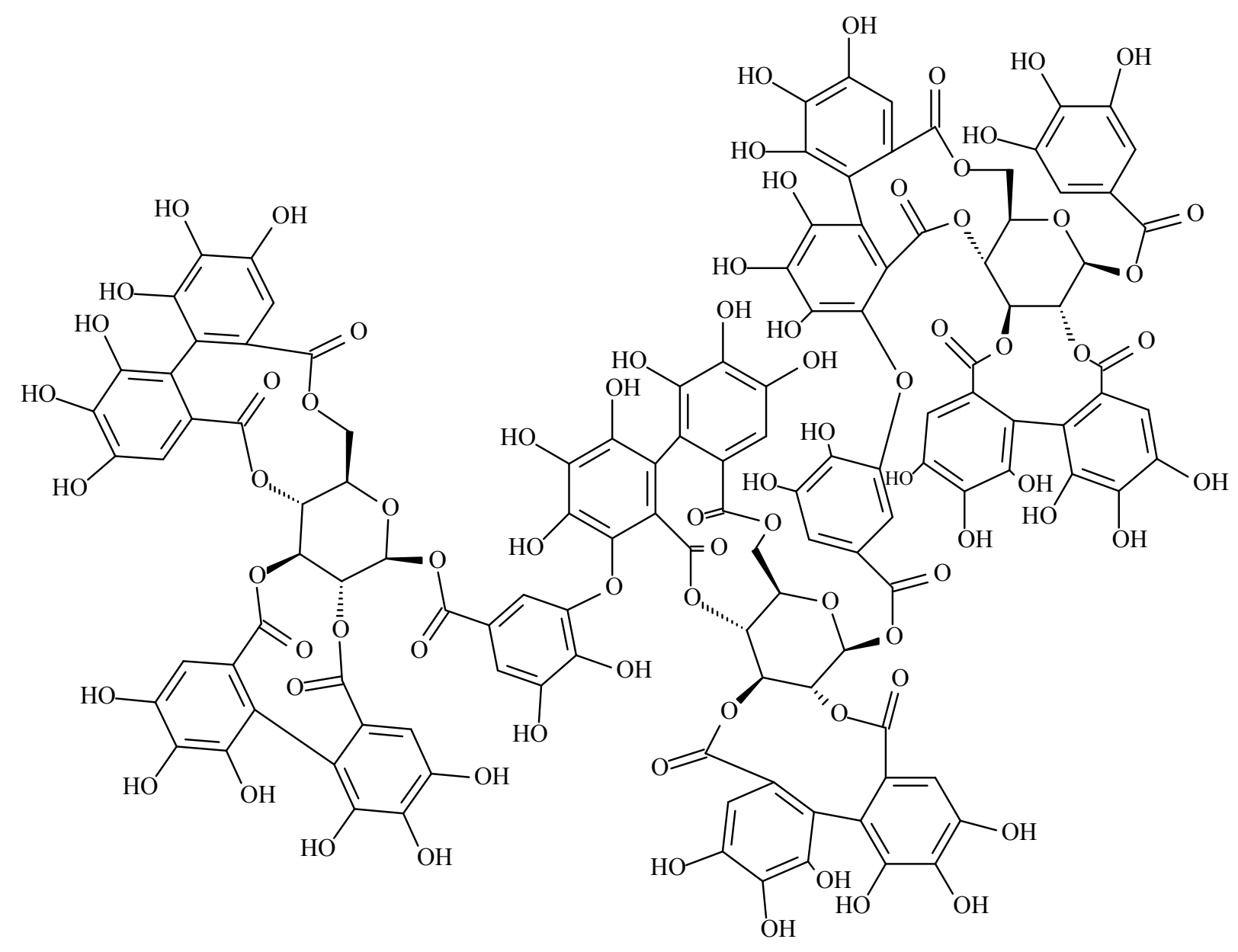

24 c rubusuaviin $C$

Figure 3. Tannins presenting $\alpha$-amylase inhibition activity (Continued.....) 


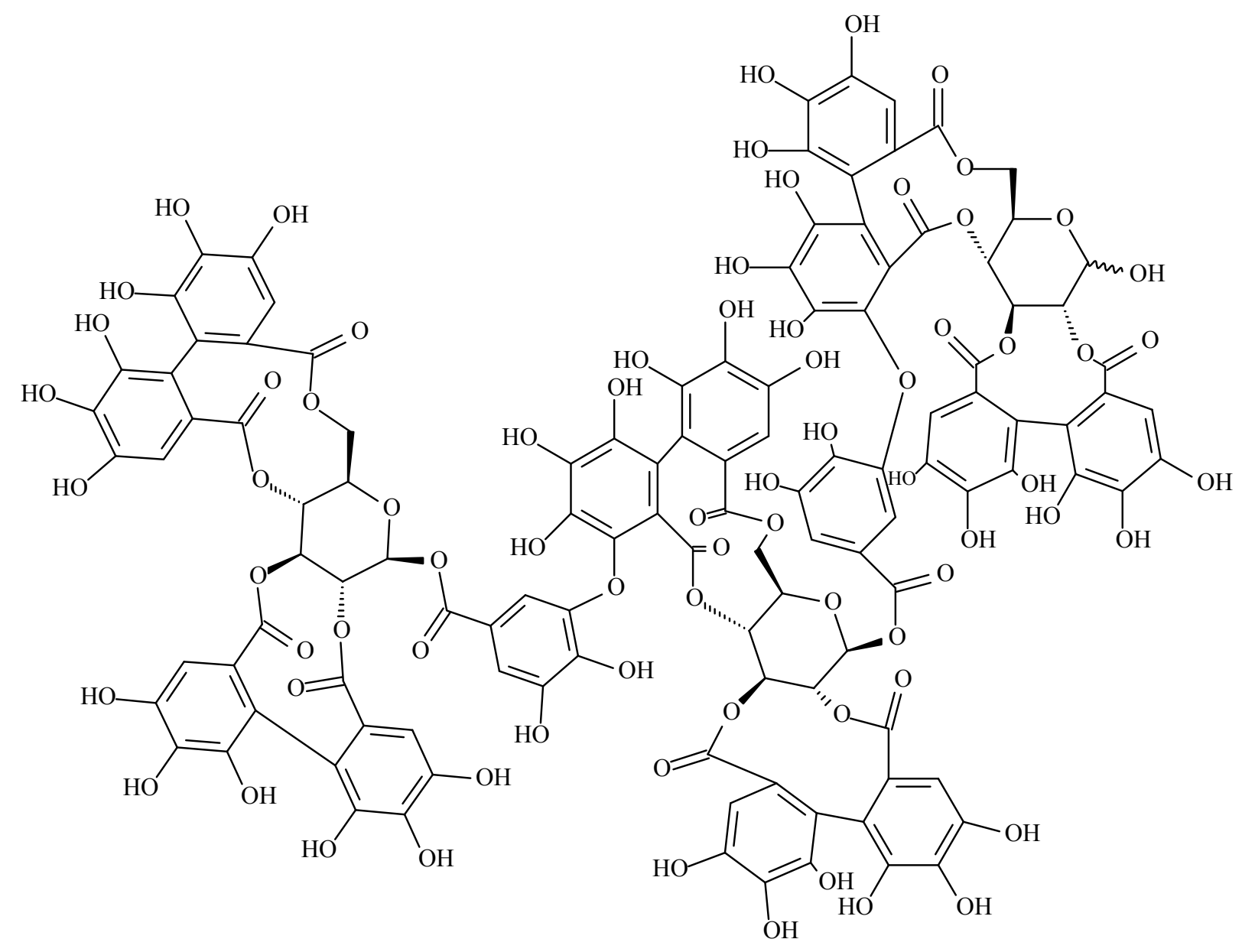

$24 d$ rubusuaviin D

Figure 3. Tannins presenting $\alpha$-amylase inhibition activity (Continued.....) 


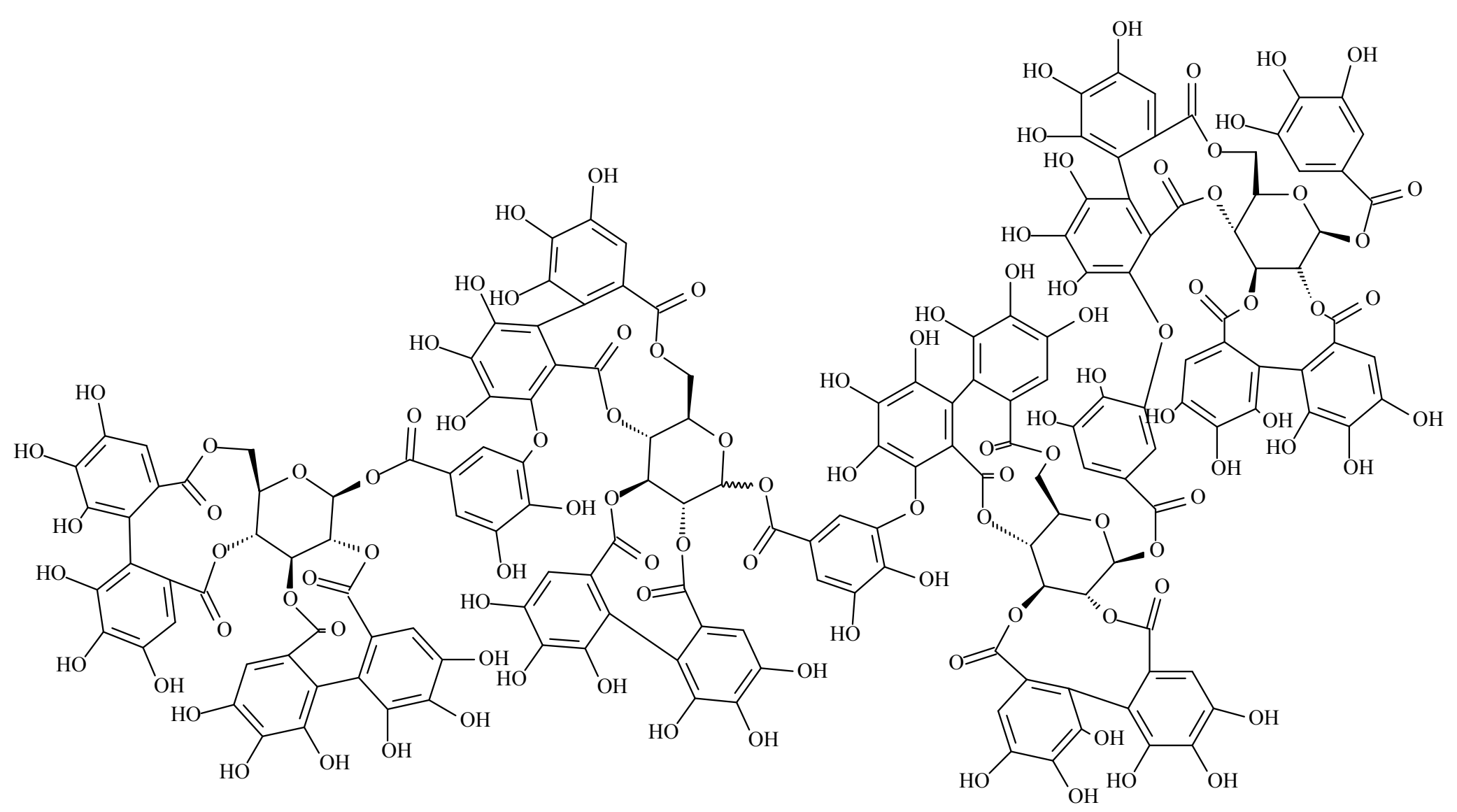

$24 \mathrm{e}$ rubusuaviin $\mathrm{E}$

Figure 3. Tannins presenting $\alpha$-amylase inhibition activity (Continued.....) 


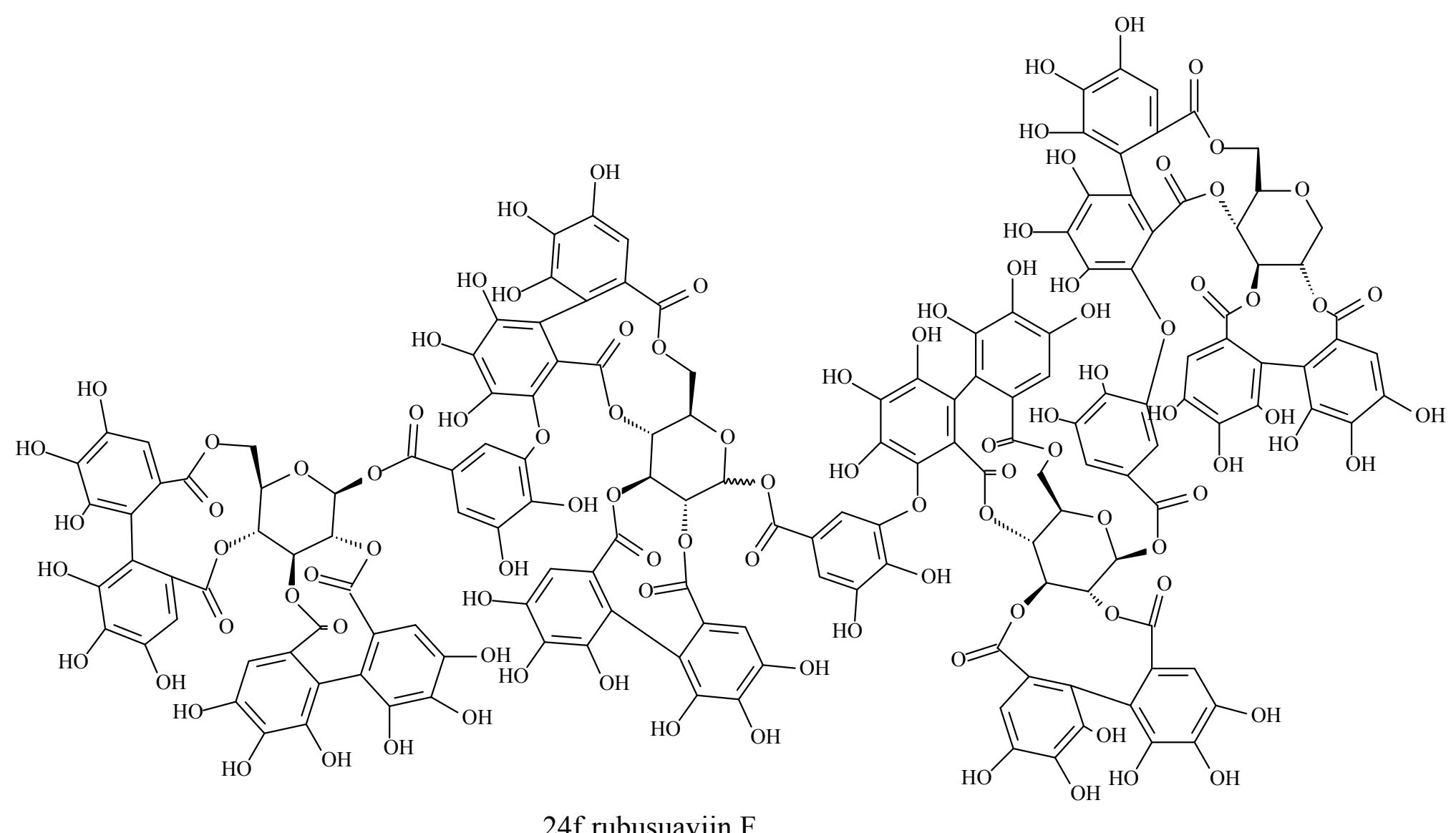

Figure 3. Tannins presenting $\alpha$-amylase inhibition activity (Continued.....) 


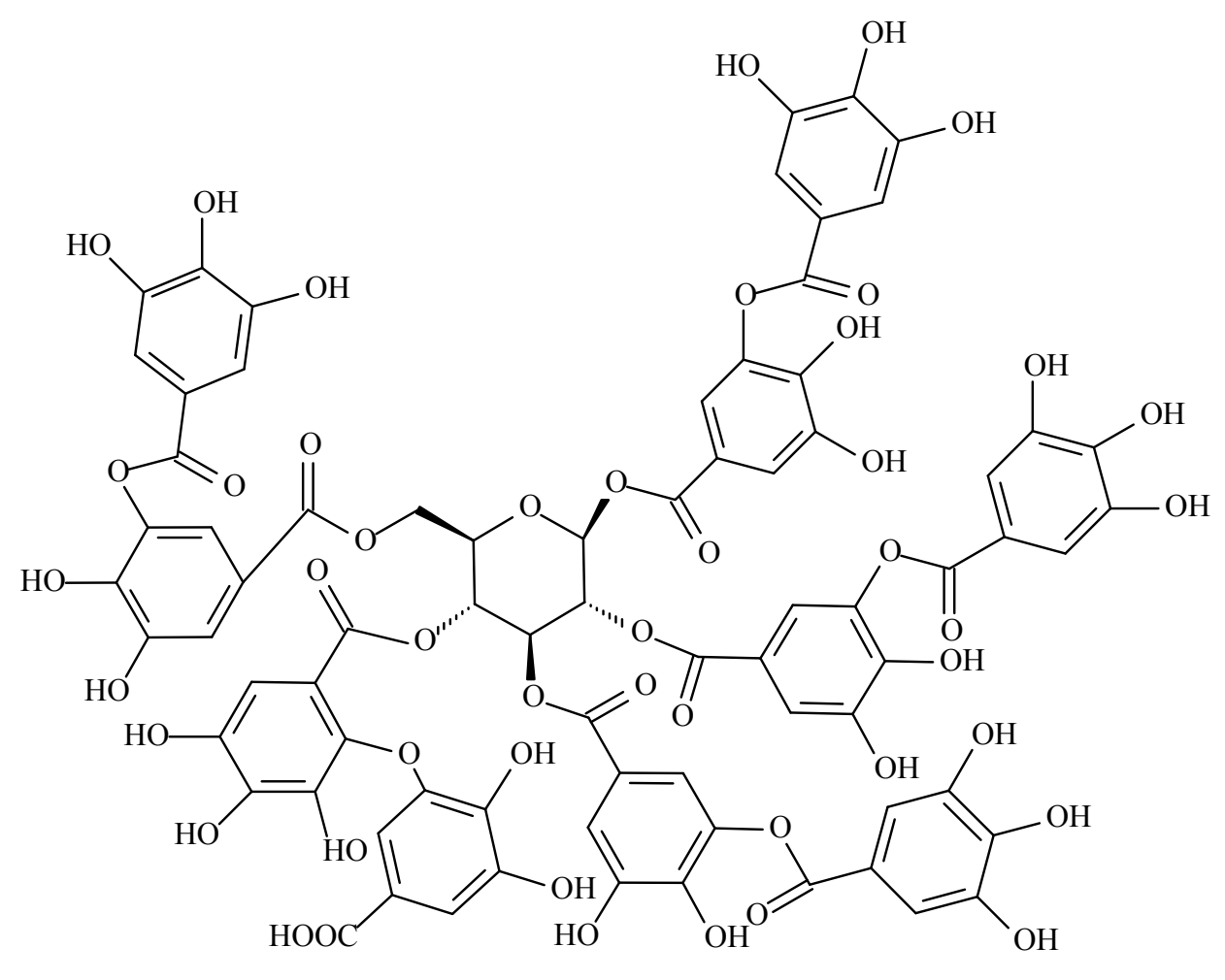

25 tannic acid

Figure 3. Tannins presenting $\alpha$-amylase inhibition activity (Continued.....) 


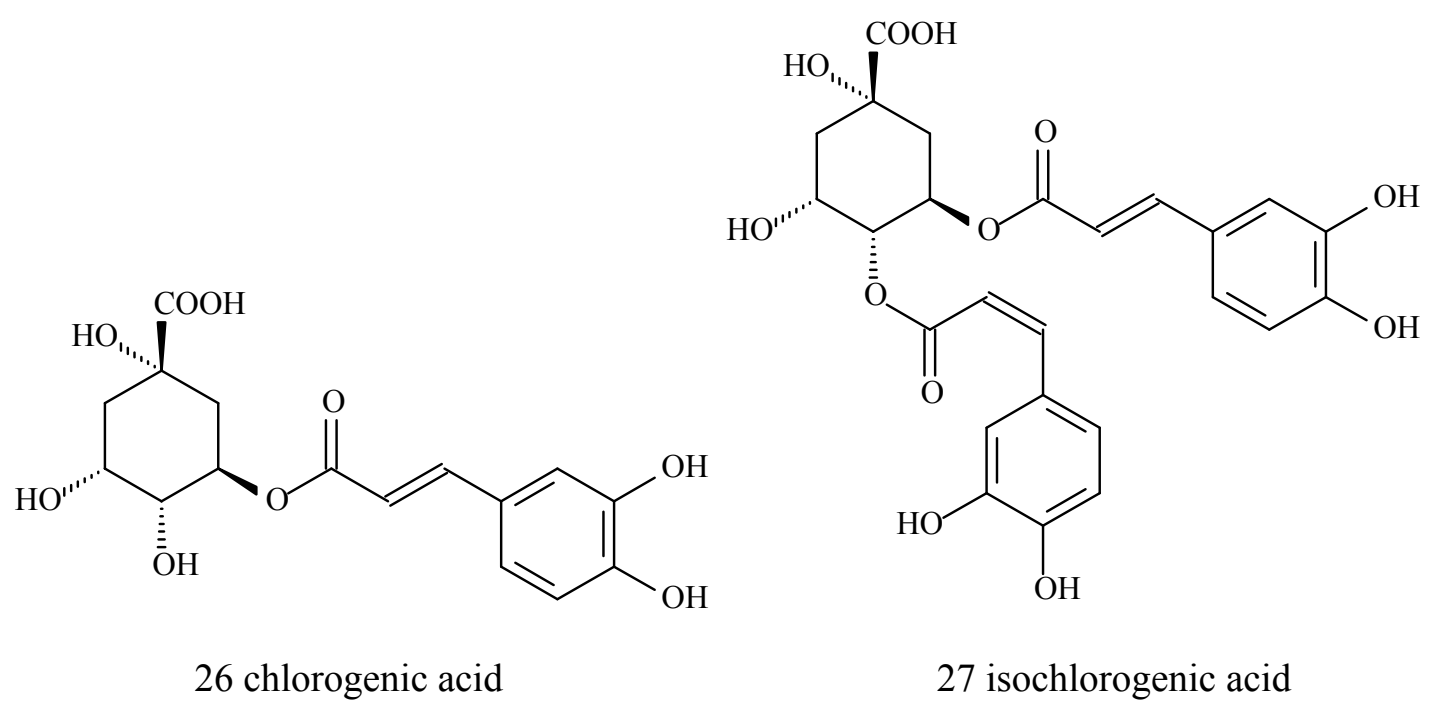

Figure 3. Tannins presenting $\alpha$-amylase inhibition activity (Continued.....) 
<smiles>O=C(/C=C/c1ccc(O)c(O)c1)OC(Cc1ccc(O)c(O)c1)C(=O)O</smiles>

28 rosmarinic acid<smiles>O=c1ccc2cc(O)c(O)cc2o1</smiles>

29 esculin<smiles>CCOc1cc(/C=C/C(=O)O)ccc1O</smiles>

$\mathrm{R}$

$32 \mathrm{a} \mathrm{H}$

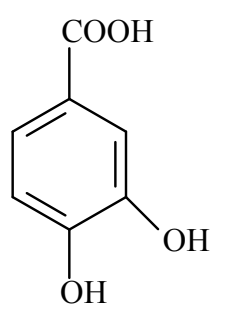

30 protocatechuic acid<smiles>O=c1oc2c(O)c(O)cc3c2c2c(c(O)c(O)cc12)OC3O</smiles>

31 ellagic acid

Figure 4. Cinnamic acid derivatives presenting $\alpha$-amylase inhibition activity 


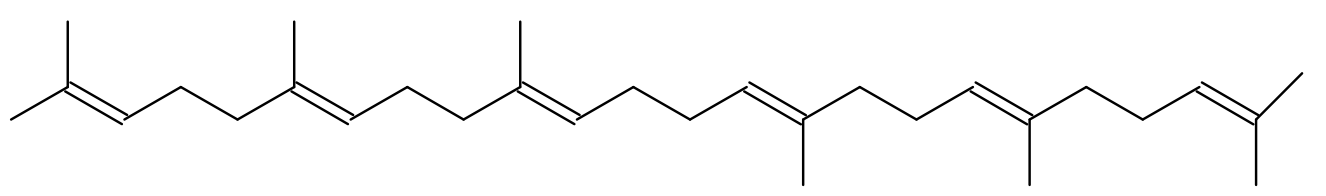

33 squalene

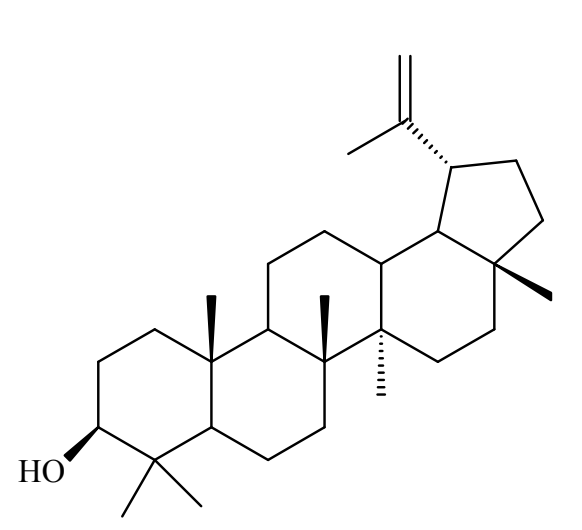

34 lupeol

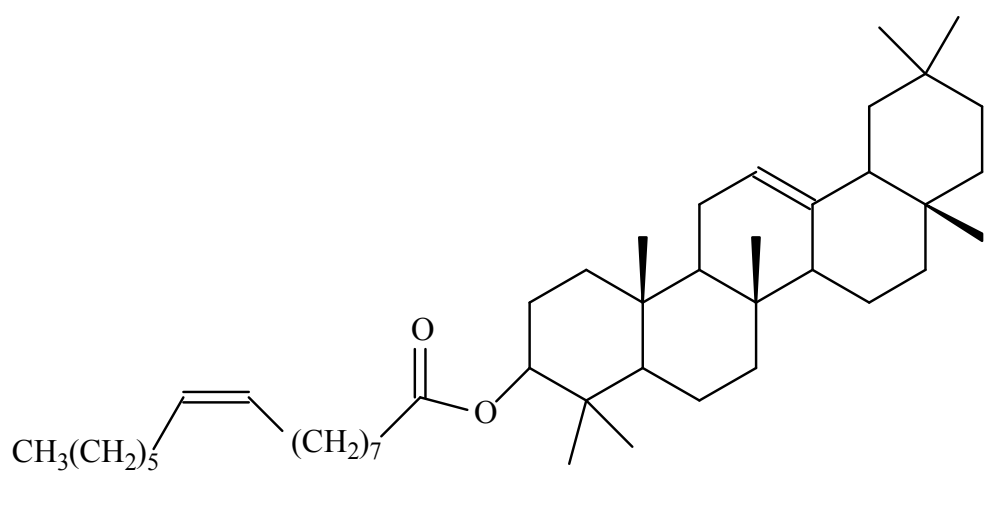

35

Figure 5. Terpenes presenting $\alpha$-amylase inhibition activity 


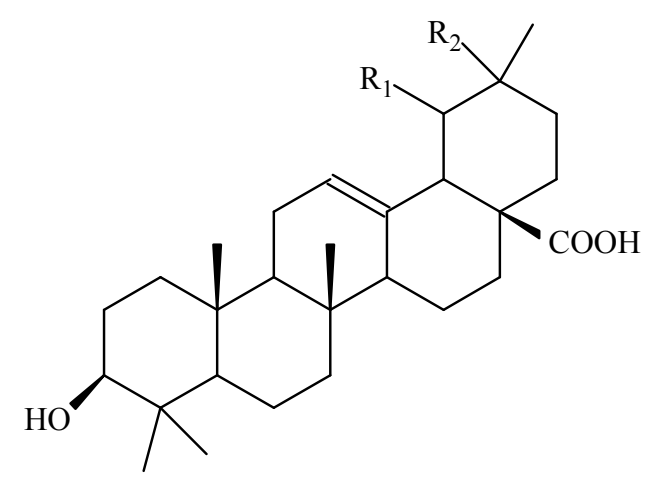

$\mathrm{R}_{1} \quad \mathrm{R}_{2}$

36a $\mathrm{H} \quad \mathrm{CH}_{3}$ oleanoic acid

36b $\mathrm{CH}_{3}$ H ursolic acid

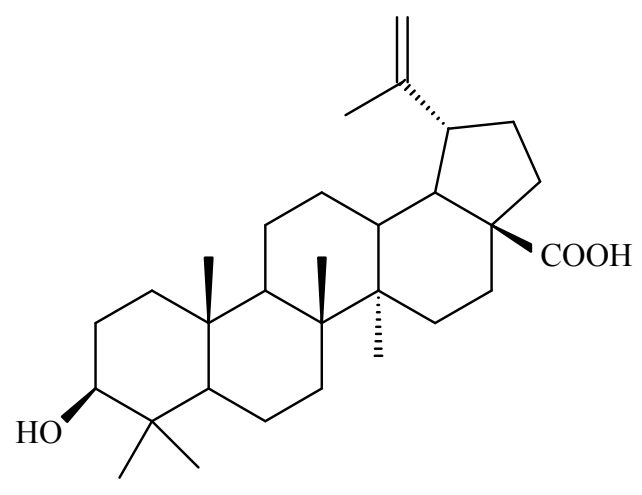

37 betulinic acid

Figure 5. Terpenes presenting $\alpha$-amylase inhibition activity (Continued.....) 